\title{
Production of Space and Social Cohesion: Roma, Iraqis, and Locals in the Ankara Neighborhood of Demirlibahçe*
}

\author{
Mekânın Üretimi ve Sosyal Uyum: Ankara'nın Demirlibahçe \\ Mahallesindeki Romanlar, Iraklılar ve Yerel Halk
}

\author{
Hakkı Ozan KARAYİĞİT \\ Syracuse University, Maxwell School, Department of Geography and the Environment, Syracuse, NY, USA \\ Syracuse Üniversitesi Maxwell School, Coğrafya ve Çevre Bölümü, Syracuse, New York, ABD \\ hkarayig@syr.edu \\ ORCID ID: 0000-0001-7633-3598
}

DOI: $10.5505 /$ jas.2021.53244

\begin{abstract}
This research investigates the relationship between social cohesion and the production of space through the socio-spatial transformations that four specific streets of Ankara's Demirlibahçe neighborhood have been experiencing. The primary aim of focusing on these four streets, which have been appropriated by three communities (Roma, Turkmen migrants from Iraq/Telafer, and locals) is to scrutinize how the production of space in particular streets hampers possible social cohesion at the local level. These streets have seen ongoing and contentious spatial practices since the massive influx of Iraqi migrants in 2014. Thus, a second aim of the study is to investigate to what extent immigrants' spatial practices become the basis of their sense of belonging, while in return creating differential spaces within the streets where preexisting social cohesion between the locals and Roma is reshaped. Through the use of a total of 60 in-depth and group interviews, which have been conducted using convenience and snowball sampling, the aim is to both describe, and critically engage, with relevant social cohesion studies and projects. The study presents the ongoing socio-spatial transformations within the Demirlibahçe neighborhood, through tracing three groups' social cohesion processes in/to space and community.
\end{abstract}

Keywords: Production of space, Social cohesion, Neo-Ottomanism, Mimesis, Demirlibahçe Neighborhood, Ankara

\section{Öz}

Bu araştırma Ankara Demirlibahçe Mahallesi’ndeki dört ana sokakta gerçekleşen sosyo-mekânsal dönüşümlere dayalı mekân üretim süreci ile sosyal uyum meselesini incelemektedir. Çalışma, Romanlar, Irak'ın Telafer şehrinden gelen Türkmen göçmenler ve yerel halktan oluşan üç grubun yoğunlukla bulunduğu bu dört farklı sokağa odaklanarak, ilk olarak bu sokaklarda gerçekleşen mekân üretimi pratiklerinin sosyal uyumu yerel ölçekte nasıl sekteye uğrattığını ortaya koymaktadır. 2014 yılında Iraklı göçmenlerin yoğun bir şekilde mahalleye gelmesine bağlı olarak bu sokaklar, günümüzde gerilimli bir şekilde gerçekleşen mekânsal pratiklere ev sahipliği yapmaktadır. Bu doğrultuda, etnografik saha araştırmasına dayanarak ikinci olarak göçmenlerin mekânsal pratiklerinin aidiyet oluşumuna etkisi ve bu etkinin Romanlar ve yerel halk arasındaki hâli hazırda mevcut olan sosyal uyuma katkısı

\footnotetext{
* This article is based on a Master's thesis with the same title, which was written under the supervision of Prof. Helga Rittersberger Tilıç, Middle East Technical University, Institute of Social Sciences, Department of Urban Policy Planning and Local Governments (UPL). The research performed in this article received the Koç University VEKAM 2020 Research Award.

** Bu çalışma Orta Doğu Teknik Üniversitesi, Sosyal Bilimler Enstitüsü Kentsel Politika Planlaması ve Yerel Yönetimler (UPL) Anabilim Dalinnda Prof. Dr. Helga Rittersberger Tilıç danışmanlı̆̆ında gerçekleştirilen ayn başlıktaki yüksek lisans tezine dayandırılarak hazırlanmıştır. Makaleye konu olan araștırma Koç Üniversitesi VEKAM 2020 Araștırma Ödülüne hak kazanmıștır.
} 
tartışılacaktır. Uygunluk ve kartopu örneklemi ile gerçekleştirilen toplamda 60 adet derinlemesine ve grup mülakatları vesilesiyle sosyal uyum alanında yapılan çalışma ve projelere eleştirel bir bakış açısı sunmak amaçlanmaktadır. Nihai olarak bu araştırma, üç grubun topluma uyum süreçlerini mekân üzerinden değerlendirerek Demirlibahçe Mahallesi'nde gerçekleşmekte olan sosyomekânsal dönüşümleri ortaya koymayı amaçlamaktadır.

Anahtar sözcükler: Mekânın üretimi, Sosyal uyum, Neo-Osmanlıcılık, Mimesis, Demirlibahçe Mahallesi, Ankara

\section{Introduction}

The neighborhood of Demirlibahçe, which is located within the municipal borders of Mamak district, is one of the very few areas that have not been transformed by the large-scale gentrification projects on the districts which have been conducted since the late-2000s (Figure 1). However, the neighborhood has gone through a series of socio-spatial transformations since the arrival of Iraqi Turkmen immigrants in 2014. These transformations are particularly concentrated in four streets that have been appropriated mainly by the following three groups - the locals, the Roma, and the Turkmens.

Uzgörenler St. is the main artery which serves as the commercial center of the neighborhood. The street's western side, near to Cebeci, is mainly populated by locals due to the high prices for the fixed capital, except for a few commercial properties occupied by Turkmens.
However, there is a much larger concentration of Turkmens towards the eastern part of the street and along Ağaçlı St. While the center of their main residential area is Doğanbahçesi St., which is parallel to Uzgörenler St., Ağaçlı St. serves as a commercial center for Turkmens. The Roma, on the other hand, live on Demirkapı St., which is parallel to Doğanbahçesi St.

Despite these three different groups living in close proximity to one another, social cohesion within the neighborhood is limited. Although there are a variety of social and institutional gathering points in the district, such as the office of the community leader on Demirkapı St., three wedding salons on Doğanbahçesi St. and Uzgörenler, various coffeehouses or Kahvehanes, (two on Uzgörenler and Doğanbahçesi, one on Ağaçli, and two on Demirkapı) and a gentrified primary school, there is little evidence of any progresses towards greater social cohesion.

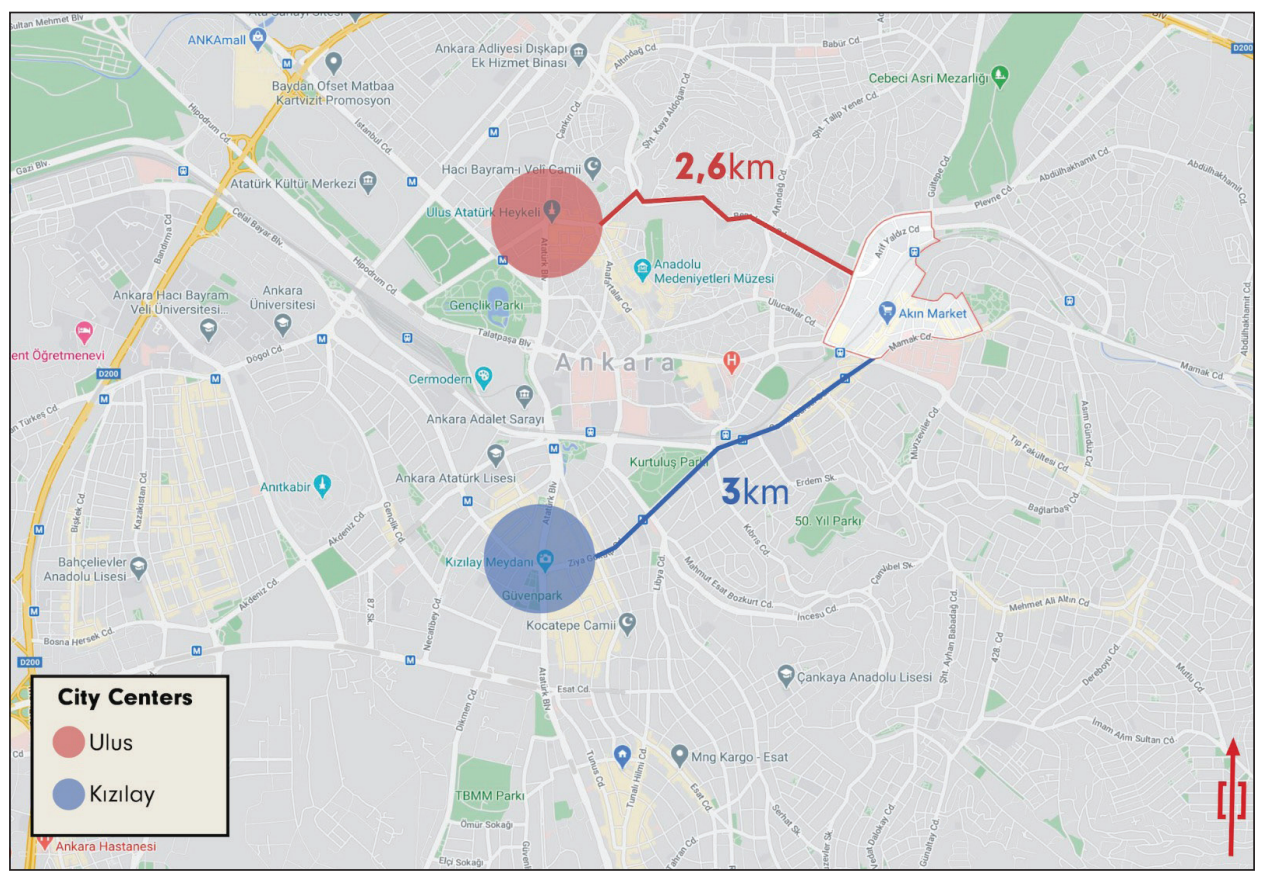

Figure 1. The Demirlibahçe neighborhood and its distance to the city centers of Ulus and Kizılay. Source: Google Maps. Accessed in February 2021. 
The term social cohesion has become rather overused in policy projects and scholarly conceptualizations of migration studies. That said, it is generally assigned a reductionist definition in policy oriented projects, defined as the absence of any social tension between refugees and host communities in non-camp urban areas (WFP, 2020, p. 5; UNDP, 2020, p. 7). Centered on the concept of trust, its scholarly classical conceptualization refers to the willingness of members to stay within the group (Festinger, 1950; Friedkin, 2004). Amid the increase in forced migration across the globe (Saggar, Somerville and Ford, 2012), the term is extended to refer to inter-group 'harmony', through which a migrant population is able to retain its cultural identity within the host society (Hoffmann and Samuk, 2016; İçduygu and Şimşek, 2016). In this regard, focus is usually centered on local level analysis, particularly at the neighborhood level (Hewstone, 2015).

However, it is often the case that even with this focus on the neighborhood, the role of space and its production (Lefebvre, 1991) are disregarded. Although migration studies facilitate urban concepts, such as the right to the city (Dikeç and Gilbert, 2002; Varsanyi, 2006), there is an apparent lack in the literature of any investigation that considers social cohesion through the production of space.

This study therefore aims to contribute to this gap in both urban and migration studies by tracing the historical transformations of one of Ankara's rooted, but less well-known, neighborhoods. In order to emphasize the role of space in social cohesion and migration studies, this study considers two main research questions I-) how the production of space in four particular streets hampers possible social cohesion at the local level, and II-) to what extent immigrants' spatial practices concretize their sense of belonging, while conversely creating differential spaces within the streets where preexisting social cohesion between the locals and the Roma is reshaped. To this end, the article consists of two main sections. Firstly, the literature on urban migrants and social cohesion is reviewed. Operationalizing Lefebvre's spatial trialectics (1991), a theoretical framework is developed to ground the investigation for social cohesion. Secondly, the findings of the research are analyzed in three aspects: perception of space and spatial practices, conception of space and political economy, and lived space and culture.

\section{Methodology}

Since I was born, raised, and spent my childhood on Dügün Street in Demirlibahçe, a short discussion on the positionality of the researcher is required. The history of my family in Demirlibahçe dates back to the 1950s when my grandfather's father came to the neighborhood and worked as a blacksmith in his own workshop. Dwelling firstly on Akpinar St. in a self-constructed villa-looking apartment, my family then moved to Dügün St. in the early 1970s when the apartment was first built. However, my grandparents' interaction with their neighbours - such as chatting, exchanging favors, and knowing the details of each other's lives (Guest and Wierzbicki, 1999, p. 93) was limited to only Dügün St. I also cut my ties with the neighborhood after 2007, although I do continue to live there off and on.

Although in this study I have taken advantage of my own personal experiences as a resident, I locate myself as an outsider, and have stood apart from the social phenomenon being investigated (Blaikie, 1993, p. 11). While being a resident has allowed me to reach out to the people, I always presented myself as researcher when conducting interviews. It can therefore be seen that my role is a combination of two extreme poles: an expert and learner. In exploring how the three identity groups construct the other, I was a learner, whereas I was an expert in the original modeling of the research project.

The logic of research utilizes both retroductive and abductive strategies. Amid increasing tension and exclusionary practices, the intention is to uncover the reasons or, more specifically, "locate the real underlying structure(s) or mechanism(s) that is (are) responsible for producing an observed regularity" (Blaikie, 1993, p. 9) by using the "knowledge that social actors use in the production, reproduction and interpretation of the phenomenon under investigation" (p. 10).

After receiving Ethical Committee Approval on 2 November 2021 from my home university, a total of 60 semistructured interviews (34 locals, 10 Roma, and 16 Iraqi) were conducted. However, before approval was obtained, I informally chatted with the ordinary residents and shopkeepers of each group, as well as with the Demirlibahçe Police Commander (karakol amiri), and former Demirlibahçe Primary School teachers. Interviews began with 'ground tour' (Saraçoğlu, 2008, p. 32) questions that 
I ask to interviewees to reflect upon the process. These questions facilitate a comparison of today's Demirlibahçe with its past, and a reflection on the major factors for the changes. A similar set of questions are directed to each group with minimal editing. The names of respondents in the text are not given, but are instead abbreviated by three codes: TR for locals, RM for the Roma, and IR for the Turkmens.

In addition, I examined the Facebook pages - Ankara Demirlibahçe' $m^{1}$ and Demirlibahçeliler biz bir aileyiz, ${ }^{2}$ which were created by the initial residents, most of whom have now moved away from the neighborhood. Following the method known as netnography, the cyber space is considered as a form of social world in order to assess how the online and offline worlds interact and shape each other (Galip, 2017; Kozinets, 2011). My involvement in the groups allowed me to reach out to the initial residents who informed me about the history (which goes back to the late 1960s) of the neighborhood.

Snowball and convenience sampling were used for the official interviews. However, in order to maintain representability and reliability, all age groups (ranging from 91 years to 16 years old) were represented in the sample. The economic class statuses of the participants are lower- and middle-income, based on the hunger threshold of 2865 Turkish Lira in June 2021 (TDS, 2021).

The extracted data is further contextualized with maps. Based on participant observations of the streets (Bernard and Gravlee, 1998), the maps are created with layering and stain techniques (Corner, 1999, p. 235; Sargin, 2012). Displaying the centralization points of the three groups in four streets, the aim is to illustrate land use strategies and explain how these strategies transform the neighborhood by shaping the perception and conception of the other, the self, and Demirlibahçe.

\section{Urbanization of and Urbanism in the Neighborhood of Demirlibahçe}

Demirlibahçe's initial urbanization process started with the establishment of Musiki Muallim Mektebi (the Music
Teachers College) in 1924. Muallim Mektebi was established under the civilizing mission of the Republic, and was part of the modernization process of Ankara after its declaration as the capital on 13 October 1923 (Günay, 2012). The Muallim Mektebi was originally situated in what was the urban fringe of Ankara, and later became the State Conservatory in 1936. The State Conservatory was a center for young composers (Şahin and Duman, 2008, p. 264) and attracted more people to settle in the neighborhood. Following the establishment of Ankara University Medical Faculty (1945) and Demirlibahçe Primary School (1949), doctors and teachers, who were regarded as elite professions, started to move into the neighborhood.

In addition to initial urbanization, the neighborhood was also a center for rural-to-urban migrants from the peripheries and from other cities. During the massive migration to Ankara throughout the 1950s and 1960s (Yavuz, 1981, p. 32; Kaya, 2002), Demirlibahçe became a hub for the middle and lower-middle class. Although some of the initial residents moved into the Bahçelievler neighborhood ${ }^{3}, 4$, the construction of housing for railway workers and the headquarters of the Organization of Post and Telegraph (PTT) during the late 1950s and early 1960s, created a self-sustaining urban scene in Demirlibahçe (see figure 2).

Also attracting the military personnel who worked in the Cebeci Military Sewing Workshop (Cebeci Askeri Dikimevi), the neighborhood established its own unique urban characteristics. Perceived as being "a lower class but also an elite place" (Cantek and Zirh, 2014, p. 154), it became a class-heterogeneous neighborhood during the 1970s. Famous Turkish Classical musicians, such as Atilla Mayda, Muazzez Ersoy, Muazzez Türüng, Neşet and Leyla Ertaş, lived together with teachers, doctors, military personnel, rural-to-urban migrants, and students from law, politics and medical faculties.

The Roma population started to move in, especially in Demirkap1 St. ${ }^{5}$, during the political conflict between the right and left during the 1970s. However, the first major

1 "My beloved Demirlibahçe"

2 "Residents of Demirlibahçe, we are family"

3 Ankara’s first permitted zoning area for a garden-city project outside the urban fringe in 1935 (Mumcu-Uçar and Özsoy, 2006).

4 A member of my grandfather's family was among those who moved from Demirlibahçe to Bahçelievler in the 1960s.

5 Demirkapı St. was an important place during the left-right conflict in the 1970s. Atatürk Dormitory (Atatürk Site Yurdu) was established in that street, and was home to mainly right-wing students. It is now being gentrified into a larger dormitory ("BirGün," 2020). 
demographic transformation emerged in Demirlibahçe following the 1980 military coup. As the Roma population agglomerated further in Demirkapı St., the 'lower class elites' moved out towards the western skirts of Ankara.

Having been subjected to a series of exclusion and stigmatization measures since 11th century Constantinople (Marsh, 2010; Özateşler, 2014; Uzpeder, DanovaRoussinova, Özçelik and Gökçen, 2008), the ongoing negative perception of the Roma population followed them to Demirlibahçe. Their cultural life based around music has been seen as idleness (Gürboğa, 2016), and their skin color, leading them to be referred to as 'darkskinned citizens' (Akkan, 2018), has been perceived as a threat.

The common working environment of the Roma only served to fuel these negative perceptions. Moving from the Marmara region in the 1950s, many Roma came to work in Ankara's developing music sector in Ulus ${ }^{6}$. Living initially in the historical Hamamönü area of Ulus, many

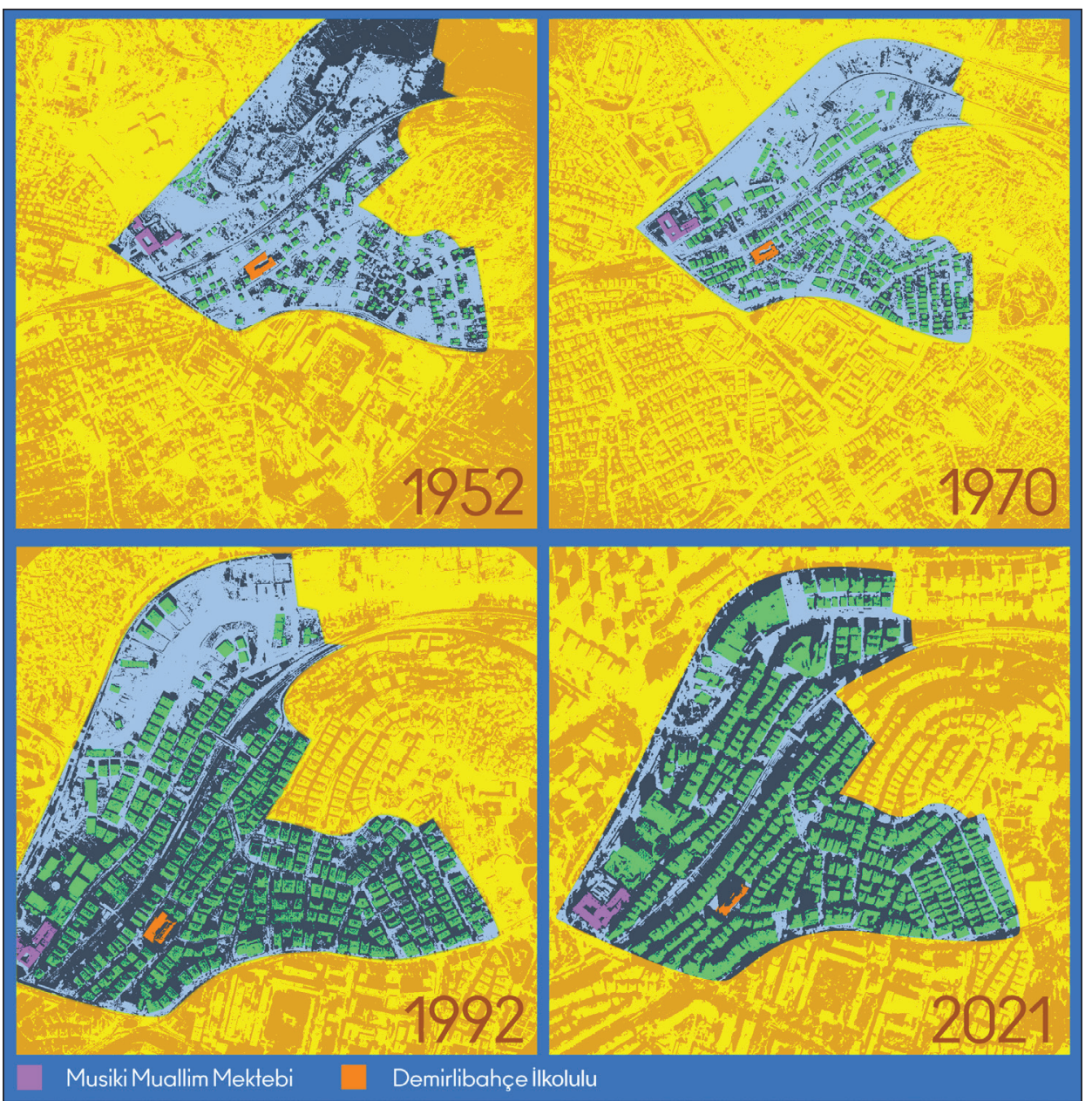

Figure 2. Aerial photographs of the neighborhood of Demirlibahçe from 1952 to 2021.

Source: General Directorate of Mapping. Edited by M. Gürkan Gürler. 
Roma played in musical restaurants, night clubs, and in pavyons. While pavyons mainly catered for the upperclass till the 1950s, they later became known as being barrel houses for rowdies (Sağlık, 2020, p. 54). While maintaining their expensive service structure, pavyons became simulation spaces (Aktaş, 2020) where the rural rich would go to indulge masculine characteristics such as interacting with konsomatris or b-girls, whose job was to chat with the visitors (Sağlık, 2020, p. 56). Such negative portrayal of pavyons only became more pronounced due their portrayal in Turkish Cinema during the 1980s, and this led to the Roma musicians affiliated with these places becoming even further marginalized. Their artistry in playing instruments became downgraded due to its distance from Western style music (Yükselsin, 2009, p. 455), and the sense that Roma's cultural orientation in music was just another name for being idle further exacerbated their socio-economic exclusion.

That said, the Roma who participated in this research actually expressed their satisfaction with their socioeconomic status. As the majority had moved from gece$k o n d u^{7}$ and into apartments, which began to be seen as a modern form of dwelling during the 1960s (Gürel, 2016, p. 39; Bozdoğan, 2010, p. 405), this group saw their new status as an upgrade. Most Roma had been forced into gecekondu areas, which were associated with criminal activities such as robbery and drug trafficking as a result of rapid urbanization, and so it was not surprising that the Roma population were relieved to be able to move. Still, their increasing numbers in Demirkapı St. was not generally welcomed by the locals during the 1990s and 2000s since negative perceptions of them caused reflexive exclusionary discourses (Rizzi, 2020).

However, over the course of 40 years, the Roma and local populations have established social cohesion based on trust. The same cannot be said of more recent arrivals, namely the influx of Turkmens from Telafer ${ }^{8}$ since 2014, which has caused another transformation in the demography of the neighborhood (Figure 3). With the help of former Iraqi residents working with real estate agents, the neighborhood has become a hub for Turkmen immigrants. As the increased demands for housing has caused housing prices to skyrocket, their arrival has become a source of both economic satisfaction through fixed capital, and dissatisfaction due to socio-cultural change.

Despite the exploitation of increased housing demands by the locals controlling the 'production in general' of particular branches of fixed and exchange capitals (Marx, 1993), many of the Turkmens who moved into the region have started their own small-businesses. The former's uninhabitable places, such as basements and boiler rooms, have become rental houses. Leading to a change in their initial image of being "needy refugees" (Üstünbici, 2020, p. 11), socio-cultural dissatisfaction has become coupled with an economic and spatial feeling of loss (Saraçoğlu and Belanger, 2019; Uzpeder, Danova-Roussinova, Özçelik and Gökçen, 2008). This has become particularly significant during the COVID-19 epidemic, where financial assistance provided for the Iraqi migrants has become a cause of resentment that has exacerbated already exist-

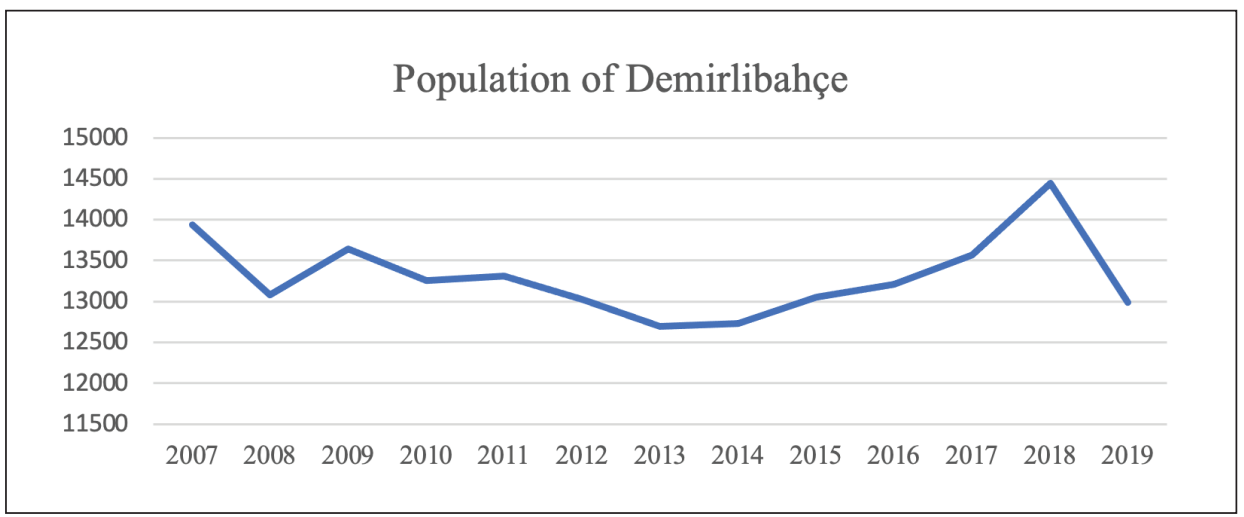

Figure 3. Demirlibahçe's demography for the last 14 years. Source: TÜIK, 2020.

7 The direct translation of gecekondu is 'built-over-night', and refers to a squatter's house.

8 A town in North-west Iraq. 
ing exclusionary discourses and spatial practices (Narl and Özaşçlar, 2020; Karayiğit, 2021, forthcoming). Figure 4 below illustrates the story-line of the general spatiotemporalities in Demirlibahçe since its first construction process.

\section{Social Cohesion and Forced Migration}

Following the massive influx of migrants from Syria, Turkey has adopted institutional changes since 2011 in order to mitigate social, cultural, and economic impacts. Targeted mainly at Syrian migrants, the leading theme of these efforts has been the 'social cohesion' discussed in both social projects and academic studies.

Considered as a policy project, the term 'social cohesion' has been borrowed from European contexts and applied in an attempt to empower 'connectedness,' 'social relations', and 'focus on common goods' (Bertelsmann Stiftung; Eurofound, 2014, p. 6; Ataseven and Bakış, 2018; Durable Solutions Platform and Migration Policy Institute, 2021; UNICEF, 2021). In the national context, five thematical areas have been determined in the mitigation of the exclusionary experiences of migrants (mainly the Syrians) - Protection, Social Protection, Education, Livelihoods, and Healthcare. The aim is to develop a community of shared values, shared challenges and equal opportunities based on a sense of trust, hope and reciprocity among the whole society (Jenson, 1998, p. 4). While the main foci are on economic balance within the society (Woolcock, 2006; Kantzara, 2016), the operationalization of the term refers to the institutional level policy planning required in order to overcome the negative outcomes of neoliberal policies such as "mounting rates of income inequality and homelessness, street crime and other forms of lawlessness, intractably high rates of youth unemployment, intergenerational dependency on social assistance, and climbing rates of child poverty" (Kantzara, 2016, p. 6).

However, mere conceptualization in policy-oriented debates has been insufficient to produce an effective outcome, and scholarly conceptualizations have investigated the structures of cohesive group formations to investigate the failure to achieve policy outcomes. As a result of such conceptualization, social cohesion has been defined as being "a set of attitudes and norms that includes trust, a sense of belonging and the willingness to participate and help, as well as their behavioral manifestations" (J. Chan, To and E. Chan, 2006, p. 290). Differing from a similar concept, social integration, ${ }^{9}$ social cohesion emphasizes "the importance of social unity within the tension between individual freedom and social order" (Seyidov, 2021, p. 113).

Collaborative measurement is achieved through the use of survey questionnaires, mainly Bogardus' Social Distance Scale (Bogardus, 1959), and by considering the concepts of social capital and social integration. Putnam's (2007) elaboration of trust and social capital determines the strength of social cohesion, although it does not apply directly to inter-group cohesiveness. Putnam states that diversity and heterogeneity, or immigration and ethnic diversity, soon "challenge social solidarity and

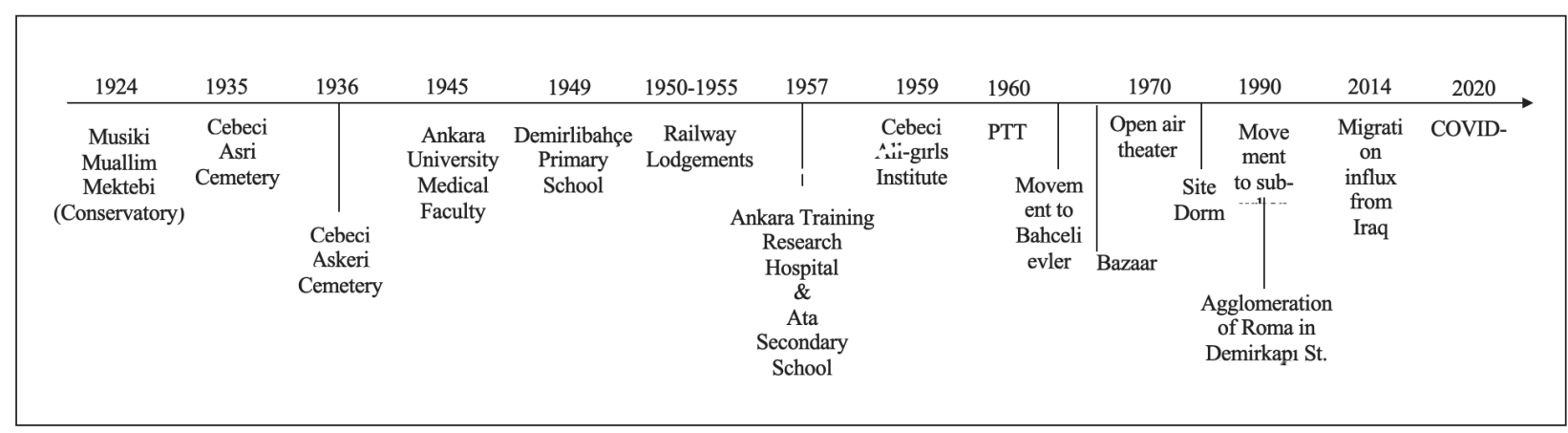

Figure 4. Story-line of The neighborhood of Demirlibahçe.

9 Social integration is defined as the regularized nature of face-to-face interactions, and is based on the reproduction of institutions for social order (Seyidov, 2021, p. 113). 
inhibit social capital" (p. 138). In other words, as people are less inclined to trust 'others', social capital becomes a competing factor in and for space.

These accounts also relate to social inclusion when encountered with two different groups who are sharing the same environment (Narlı and Özaşçılar, 2020, p. 304). In the case of migration, the concept is often used to identify inclusionary and exclusionary practices between the local and migration communities (Kavas, Avşar, Kadkoy and Bilgiç, 2019). Conflicting with populist discourses that disregard diversities (Yenigün and Eraydın, 2019), ongoing experiences with migrant groups have come to be defined as differential inclusion (Baban, Ilcan and Rygiel, 2017), due to a lack of entitlement to refugee and citizenship rights.

The literature on forced migration in Turkey dwells heavily on Syrians, and is oriented under four approaches: politico-institutional, judicial-institutional, socio-cultural, and socio-institutional.

Politico-institutional approaches mainly investigate the Turkish state's institutional patterns for the management of migration flows in relation to foreign relations (Ergüven, 2013; İçduygu and Şimşek, 2017; İçduygu, 2015; Koca, 2016; Gökçek, 2017). These epistemological approaches consider Turkey as being a black box, to use IR terminology. The focus of this approach is mainly on the governance migration patterns at the national and at the international level, rather than on migrants themselves.

The judico-institutional approach investigates immigrants' accessibility to judicial measures in their socioeconomic protection and proliferation of civil society organizations (Cankurtaran and Albayrak, 2019; Keysan and Şentürk, 2021; Ineli-Ciğer, 2017). Particularly applicable to vulnerable groups, this area of studies contributes to the totality of migration and social cohesion studies by drawing attention to judico-institutional capacity building.

The socio-cultural approach analyzes public opinion. In this approach, members of an identified community, such as Turks and Syrians, are generalized and are considered as being the same (Ekinci, 2015; Erdoğan, 2015; Efe, Pakso, and Pandır, 2015). These studies contribute to migration and social cohesion research by investigating the factors that shape the perceptions of the local and immigrant communities towards each other.
The socio-institutional approach focuses on local complexities. The main emphasis of this approach is public schools, which are considered as "habitus" (Bourdieu, 2008). These studies contribute to the process of social cohesion by analyzing the role of public institutions at the local level (Dillioğlu, 2015; Sunata and Bircan, 2015; Sezgin and Yolcu, 2016; Ara and Yasun, 2016; Erçetin, 2018; Çelik and İçduygu, 2019; Gencer, 2019; Taşkın and Erdemli, 2018).

However, with migrants in Turkey being generalized as Syrian, and Syrians being generalized in terms of the location they inhabit, an external validity problem is created with the particularities of each case being swallowed by such generalizations. It is for this reason that instead of making large urban-scale generalizations, this research strictly focuses on four streets (Türkyllmaz and Ayaokur, 2014). In doing so, this paper considers social cohesion as being "the capacity to acknowledge the existence of different social and territorial groups present in the city, their diverse and sometimes contradictory interests as well as the capacity for these groups to organize themselves and for the city to create institutions in which these groups can confront each other and decide about the city's future" (Cassiers and Kesteloot, 2012, p. 1910). Yet, the case of Demirlibahçe shows that while there is 'acknowledgement' among the groups for their 'others,' this acknowledgement is seen as something negative, namely concern for the future and a feeling of loss.

\section{Theoretical Framework}

Prior to this study, no institutional or scholarly-led social cohesion project had been conducted in the neighborhood of Demirlibahçe neighborhood. The arrival of the Turkmens has led to a reconfiguration of the social cohesion between the locals and the Roma, leading the neighborhood towards a 'social cohesion crisis' (Forrest and Kearns, 2001) due to the crumbling of the social cement of a previous era. However, there are signs that the political economy of the neighborhood is progressing towards a form of cohesion as locals, the Roma, and Iraqi migrants are conducting material exchanges. Additionally, Turkmen residents are working in various crafts (such as barbers and civil society organizations - Ottoman Turkmen Associations). Moreover, the everyday life of the three groups, according to the signs and symbols of a neo-Ottomanist agenda, exhibits cultural, social, and political commonalities. 
This study explores the production of the neighborhood space by measuring social cohesion in terms of trust, connectedness, social relations, and focus on common goods. By considering the mutually-constitutive relationship between the fields of spaces (Lefebvre, 1991), i.e. how they are perceived, conceived, and lived, the underlying structures for cohesion are revealed (Table 1).

Table 1. Social Cohesion through the Production of Space

\begin{tabular}{|c|c|}
\hline Social Cohesion & Production of Space \\
\hline Physical Sphere & Perception \\
Economic Sphere & Political Economy \\
Cultural Sphere & Lived Space \\
\hline
\end{tabular}

Lefebvre defines 'spatial practice' as "daily reality (daily routine) and urban reality (the routes and networks which link up the places set aside for work, private life and leisure)" within 'perceived space' as part of neocapitalism (1991, p. 38). In this sense, spatial practice refers to the daily life of I-) the Iraqi immigrants who are under International Protection and live in a state of partial legal inclusion/exclusion, II-) the Roma population who work under precarious conditions, and iii-) the locals whose space is threatened by and benefits from the practices of others. These spatial practices of the members of each group are examined in terms of their negative and positive perceptions of each other.

Spatial practices are performed through intervention by construction planned in the 'representations of spaces'. As such interventions are in the abstract space, they "serve profit, assign special status to particular places by arranging them in the hierarchy, and stipulate exclusion (for some) and integration (for others)" (p. 288). As the space is dominant space, the sole emphasis is on the exchange value of space, rather than its use value. Hence, these 'representations of spaces' are examined under two perspectives - the political economy of the neighborhood, and the political economy in the neighborhood, to demonstrate the instrumentalization of political economy in exclusion (Lefebvre, 1991, p. 306-313).

However, the abstract space contains its own contradictions. In the third realm of social space, representational space and everyday life, with the symbols and cultural features of the three groups, are examined. These symbols and cultural features often contradict or interact with one another. For example, under the country's current neo-
Ottomanist political agenda, these symbols help unite the differences within its mimesis while creating further political cleavage. While neo-Ottomanism was a critique of the republican 'elites' and their nation-building process under modernization, Islamic heritage was "utilized as a pragmatic means in policies to mitigate the escalating social tension resulting from identity-based claims, most notably, the Alevi and Kurdish questions" (Erdem, 2017, p. 713). However, in its current form under the regime of the ruling party (Justice and Development Party), "the neo-Ottomanist nationalist ideology is promulgated by the society itself and becomes a part of mundane everyday practice" (Ongur, 2015, cited in Erdem, 2017, p. 714). The three groups reflect the common Ottoman heritage by displaying the flags of the former Turkic States of the Ottoman Empire, and of the Uygur Khanate, inside or in front of commercial places. The tughras of the Ottoman Sultans are also hung on the walls. However, this common heritage is often rejected by those who have different political views, while cleavage is exercised over the discourses on the female body.

Although Lefebvre's spatial trialectics are absent when considering the context of migration studies, efforts under 'right to the city' contribute to this research (Lefebvre, 1968/1996). Studies argue about the possibility of urban citizenship to co-regulate urban migrants from an inclusive perspective (Gebhardt, 2016; Dikeç and Gilbert, 2002; Varsanyi, 2006). As 'right to the city' refers to the "struggles over the conditions and inequities of globalization and urban life" (Dikeç and Gilbert, 2002, p. 64), a non-bounded, but grounded, citizenship is advocated (Varsanyi, 2006, p. 239). As noncitizen status can compromise claims to the city, the Lefebvrean conceptualization targets immigrants' legal status, and thus breaks free from the "territorial trap" (Agnew, 1994) that sees earth space as consisting merely of territorial states (Karayiğit, 2021). However, assigning local citizenship status to immigrants at part of city level administration seems impossible under the centralized governmental system of Turkey.

One issue with migration studies is that they lack a spatial lens, and so are unable to capture social cohesion. When migrants' spatial practices and mobilities are mapped and analyzed (Alanyal1, 2017; Savran and Sat, 2019; Eraydın, 2017), there is no debate on social cohesion. Similarly, when the focus is on social cohesion, the roles of space and urban particularities are also omitted despite 
Özçürümez and Hoxha, 2020 talk about neighborhood scale without actually engaging with it. As 'street scales' are considered as an important factor in terms of social interaction, recognition of group identity and communication with places and people (Uslu and Gökçe, 2010, p. 2803), this study therefore identifies three pillars based on Lefebvre's spatial trialectics (Table 2).

\section{The Production of Space in Demirlibahçe and Forms of Social Cohesion}

Lefebvre indicates that social life is the unity of physical, mental, and lived worlds (Fuchs, 2019). This unity is a combination of "mentally perceiving the physical and social world; mentally conceiving this world in particular cognitive ways as thoughts; and living the world in social relations in which humans communicatively produce themselves, use-values, collective decisions, rules, morals, norms, collective meanings" (2019, p. 144). Therefore, the three pillars aspire to capture this unity in the examination of social cohesion. Firstly, construction of the self, the other, and the neighborhood is demonstrated through the negative and positive perceptions in the discourses of residents, shop owners, and real-estate agents. Secondly, the reflections of these discourses in the representation of the neighborhood space and their impacts on political economy are illustrated. Thirdly, the lived space through the cultural signs of Ottomanism and Turkishness is examined, along with their impacts on political cleavage over a woman's body.

\section{i. Perception of Space - Construction of the Self, the Other and the Neighborhood}

The Locals: Demirlibahçe's local residents emphasize the elite characteristics of the neighborhood due to its high- status inhabitants and its proximity to state institutions such as hospitals and universities. Reference is made highly to the sense of friendship, trust, and of being a part of the neighborhood.

"Can you imagine... thanks to the Conservatory, Müjdat Gezen, Mehmet Ali Erbil, Cihan Ünal, Selda Bağcan... These people passed through Demirlibahçe. They passed through the elite settlements of Ankara. And Demirlibahçe was already one of the elite places of Ankara. It was really a quality place... Neşet Ertaş... he also lived here. After that, Recep Kaymak ${ }^{10} .$. . These are the people my big brothers told me about. Maybe I've seen them too, but I don't remember because I was a kid." (TR5, Male, 1970, Realestate Agent, Uzgörenler St.).

Locals currently have positive perceptions of the Roma, with the negative ones being disregarded after encounter with the new strangers, i.e. the Turkmens. Most of the participants in the research define the Roma through comparison with the Turkmen migrants. As they have been a part of the neighborhood for over 30 years, there is generally positive feeling towards the Roma. However, some of the previous negative perceptions do persist, and these generally relate to their numbers in the streets, performance at school, way of speaking and accents, population levels, being a closed community within themselves, and the noise they make. These issues also have an impact on the political economy in terms of rentals, which I discuss in the next chapter.

"When the Iraqi Turkmen first came, the people started to love the Roma. The elite of the neighborhood used to complain about them. Now people see them as being quality. I also wish everyone was Roma. They are very clean people. If you go to a Roma house, you'll see the cleanest house

Table 2. Theoretical Framework in Detail

\begin{tabular}{|c|c|}
\hline Production of Space & Determinants of Social Cohesion \\
\hline Perceived Space & Construction of the self, other, and Demirlibahçe \\
\hline Conceived Space & $\begin{array}{c}\text { The Exchange value of Demirlibahçe } \\
\text { The Political Economy of and in Demirlibahçe }\end{array}$ \\
\hline Lived Space & $\begin{array}{c}\text { Ottomanism and Turkishness } \\
\text { Exclusion over a woman's body }\end{array}$ \\
\hline
\end{tabular}

10 All the names listed here are famous film, theatre and music artists, and folk poets. 
in your life. The façade of the house might be shabby, but the interior is amazing. They wear the best, eat the best, and live the best." (TR28, Male, 1965, Real-estate Agent, Uzgörenler St.).

"I like the Roma. Their culture and Iraqi culture are not the same. For one thing, the Roma are not dirty. Yes, they have a different life. Those here are the Roma elites. In the past, they were excluded, but look at the situation now with the migrants. Now we're seeing worse." (TR7, Female 1977, Real-estate Agent, Uzgörenler St.).

Significantly, it is now acknowledged by the locals that each of these negative perceptions are the results of the Roma's deprived socio-economic conditions. For instance, the Roma children's performance at school is now understood to be the result of their fathers' working conditions, and the same factors also relate to what is perceived as a noisy life-style. Their clothing and 'irrational' expenditures are now often seen as a part of their joyful culture. Their high population and being a closed community are now generally perceived as the reason for their secure environment.

Similar negative discourses apply also to the Turkmens. The same criticisms of the Roma (Turkmen children's performance at school, lifestyle, method of speaking, numbers in population ${ }^{11}$, and being a closed community) are seen as factors that are damaging the organic tissue of the neighborhood. Influenced by the needy image that it is believed migrants should have (Üstünbici, 2020), locals raise concerns about the Turkmens' seemingly well-off live-styles. Lastly, the locals also disregard the ethnicity of Turkmens, as their way of life is not considered Turkish, despite their reference to their Ottoman past.

The Turkmens' identification of themselves as Ottoman Turks can be seen as an attempt to self-integrate within the social and cultural aspects of the Turkish imagination (Anderson, 1991; Batuman, 2010). In fact, the definition of Turkmens is disputed in the literature. While some accounts consider Iraqi Turkmens as one of Iraq's largest minority groups, whose origin dates back to the Ottoman Empire of the $16^{\text {th }}$ century (Mercan-Sar1, 2018, p. 39), others point to the $10^{\text {th }}$ century central Asia's nomadic tribes as the origin of the Turkmens (Güngör, 2014). The term is also used to differentiate Muslim Oghuz tribes from non-Muslim Turks (Mercan-Sar1, 2018, p. 42). However, studies of 'nationalist' accounts assert that the term Turkmens was artificially created by the Iraqi government in the 1950s in order to separate the group from their cognates in Turkey (Mahmood, 2020, p. 67).

While the notion of Turkmens being Turkey's Turkish blood brothers/sisters is not fully contributing to their socio-cultural inclusion in the neighborhood, this racial representation does help to secure their legal status. There is a special condition within the legislative framework of the Law on Foreigners and International Protection (YUKK/LFIP, 2013) for the Turkmen population. According to the Ministry of Interior's circular letter on 12 February 2015 (Irak (Turkmen) Uyruklu Yabancilar, 2015), Turkmens are given i-) easy access to measures taken regarding voluntary return to Iraq, ii-) a "humanitarian residence permit" based on law no: 6458, if an individual cannot return to Iraq, and iii-) the right to apply for International Protection.

Prior to the circular, Iraqi immigrants did not have access to public healthcare since they are not given Temporary Protection status, as is the case with Syrian migrants. However, this circular, gives Iraqi Turkmens the option to choose from two ID cards - either an International Protection Applicant ID, Uluslararası Koruma Başvuru Sahibi Kimlik Kartı in Turkish, or a foreigner ID card that doesn't start with '99'. These steps have enabled the Turkmens to benefit from free health services, and have eased the process of obtaining a residency permit.

These benefits are available if the migrant is determined to be Turkmen by the Ministry of Interior, and enrollment to the system is achieved by selecting the 'Iraqi Turkmens' parameter in the section on 'Turkish Descent' (see section 3.3. of the circular). It has been observed that the Turkmens in Demirlibahçe are given International Protection when the ID card is willingly shown. With further livelihood support provided by the Ottoman Turkmen Association, ethnicity-based projections are used on a legal basis to assist social and cultural integration into the

\footnotetext{
11 Unofficial records for the number of Iraqi residents who received foreigner ID cards before January 2019 that begin with numbers other than '99' were kept by the Mukhtar (community leader), S. Hanım, on her own initiative. The figure recorded is 1173 , which represents around $8 \%$ of the neighborhood population dispersed over these four streets, but particularly in Doğanbahçesi St.
} 
scope of the Ottomanist nation-building projects advocated by the ruling AKP government (Erdem, 2017).

While the Turkmens are being accepted legally and politically, there is unrest among the locals in the neighborhood about them. The two Facebook groups have three major posts that speak out against immigrants in Demirlibahçe, and these sentiments also are present in the faceto-face interviews. The first one of these was conducted in September 2020, the second in December 2020 during the COVID-19 curfew related economic constraints, and the third interview was in February 2021. All three posts mention the loss of the neighborhood to the Turkmens. Significantly, one post (Figure 5), calls on the local residents to act against the migrants in Demirlibahçe, and suggests a petition to get the migrants kicked out from the neighborhood. The reasons given are their dirtiness, the way they stare with 'bad' eyes, and how they are reducing property values. A petition was actually organized, signed by some of the locals and presented to the Mukhtar on 21 October 2020. Yet, she refused to process it.

"If you ask why the residents of Demirlibahçe are uncomfortable, it's because the Turkmens are really rude. They are uneducated, they hang about in the middle of the road, they spit on the ground, they make noise in the buildings, and walk about without masks... And they have at least 10 children in each flat, and they continue to do it non-stop." (TR34, Male, 1983, Jeweler, Uzgörenler St.).

The first and foremost problem is seen to be their fertility rates, namely that they have too many children whom they cannot support. As the children are allowed to play freely in the streets (Figure 6 and 7), the locals perceive them as being threatening. Indeed, the wild games of the children have led to negative discourses on the basis that such behavior will have a catastrophic effect on the future of the neighborhood, and even the whole country.

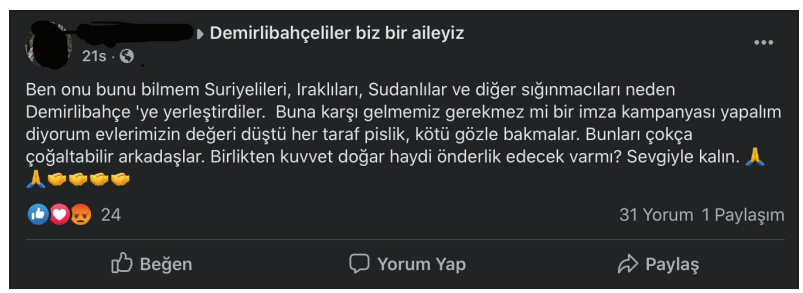

Figure 5. Facebook post on "Demirlibahçeliler biz bir aileyiz" on September 9, 2020, calling for the migrants to be kicked out of the neighborhood.
At an extreme level, the Iraqi Turkmen are even seen as potential rapists and killers by the locals. As the country now hosts the highest refugee population in the world (Christophersen, 2021), there is a lot of negative sentiment amongst Turkish citizens related to migration politics and refugees, particularly the Syrians (Akyüz, Akbaş and Onat, 2021). In the neighborhood of Demirlibahçe, locals emphasized the increased levels of fear about migrants who might commit crimes, especially against women.

I contacted the police during my field research and was informed that no physical/sexual abuse had been recorded in the neighborhood. However, some locals did tell me that they have experienced harassments, but that they decided to keep quiet about it as they didn't want the men in their family to seek revenge on the migrants.

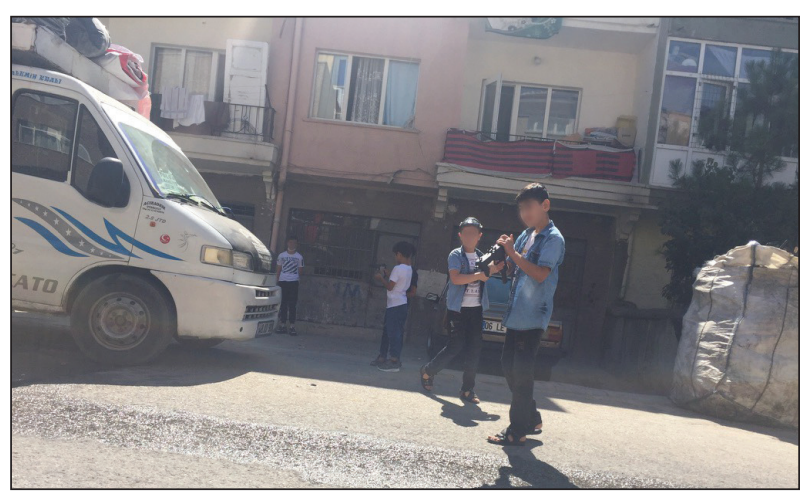

Figure 6. A picture from Eid al-adha. Children playing with toy guns in Doğanbahçesi St.

Photograph by: Hakkı Ozan Karayiğit, 31 July 2020.

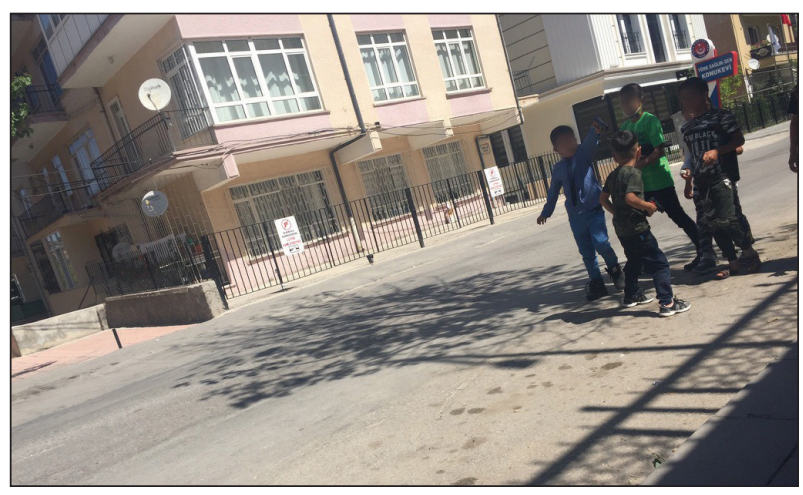

Figure 7. A picture from Eid al-adha. Children playing with toy guns in Doğanbahçesi St.

Photograph by: Hakkı Ozan Karayiğit, 31 July 2020. 
"My cousin was going to Ata Secondary School, she is very little, a young girl. A Syrian followed her for two or three days and vocally abused her. She was too scared to tell us at first. Later on, he cornered her near the school, and kissed her on the lips. There has always been harassment, but I have never seen anything like this. Our grandmother warned us not to go to the police and to keep quiet so our father wouldn't go out looking for that migrant" (TR3, Female, 2000, recent graduate, Doğanbahçesi St.).

By 'looking down' on the Roma and the Turkmens, the locals effectively position themselves in a higher status. This construction is also reinforced by perceiving Demirlibahçe as once being an 'elite' place inhabited by high-level bureaucrats, doctors, teachers, and artists. The final part of this narrative is that the minority groups the Roma and Turkmens - are perceived as being inferior communities that have difficulties in adapting themselves into the elite structure of the neighborhood.

The Roma: The Roma residents of Demirlibahçe tend to construct the self and others reactively. In other words, while they have their own perceptions, their construction of the self is exclusively formed through reaction to the negative perceptions of the locals, who they see as degrading their culture and way of life through discourses and spatial practices.

The Roma population perceives Demirlibahçe in a similar way to the locals, i.e. a place that used to be for the elite, although there is less of a feeling of belonging. Their motivation for moving to the neighborhood is nearly always defined by their work (i.e. being close to night clubs and restaurants) and the preference of living in apartments instead of in gecekondu. While Roma men tend to focus on the economic aspects of Demirlibahçe, the women usually refer to the neighborhood's closeknit community. As most of the women are financially dependent on their husbands, it often takes a while for them to develop any perception of the neighborhood. However, once they have, it is often the relationships they have with other neighbours which they cherish.

"Perhaps the best thing about living in Demirlibahçe is that we are still neighborly. Although I told you that I would like to live in the neighborhood of Çiğdem, I don't think I would make such close relationships there. Over there, you can't just leave the door open, or give your house's key to someone else. But here, I can still leave my door open or give the keys to a neighbor." (RM1, Male, 1995, Musician, Demirkap1 St.).
"Well, we are inseparable now, and none of us wants to live in another neighborhood. Everyone knows everybody now. We see Ayşe while walking, we see Fatma. We're chatting. Men go to work; women go to chat. We have a street culture." (RM 6, Female, 1986, Housewife, Demirkapı St.).

In their reaction against the negative perceptions towards themselves, Roma participants in the study initially refer to the lack of opportunities provided to them by the government institutions. They believe that the quality of their music comes from talent, rather than education, and they expect to be appreciated for having such innate talent contributing to Ankara's cultural life. By referring to Atatürk, the founder of the Republic, Roma thus challenges the self-construction by the locals as being elites.

"When we first came here, we used to say Çamurlu Bahçe (or Muddy Garden in English) instead of Demirli-bahçe (Iron-garden). There was mud everywhere. At that time, there was one filthy man, not to mention his name. This man didn't give any of us, especially musicians, a home since we first arrived (late-1970s). He used to say, "these are Roma, I don't give them a home." However, as Atatürk said, "you can be anything, but you cannot be an artist." Because we make art, I do not understand why this discrimination exists." (RM5, Male, 1967, Musician, Demirkap1 St.).

Participants are also offended by the discourses produced by the locals which perceive the Roma as being dishonorable. These include accusations that the Roma do not pay their debts to grocery stores, are disloyal, often steal, and that such things are covered up by the Roma population. However, the Roma in the study also created 'othering' discourses against Roma communities (gypsies) who live in other parts of the world.

"We do not behave badly. Men gather here and chat with their friends. They talk about their daily lives and then they disperse. Then everyone goes home, washes, and goes to work. Hygiene is very important to us. It existed before the pandemic and now it continues." (RM4, Female, 1965, point lace, Demirkapı St.).

"You must distinguish us from other Roma communities. What distinguishes us from others is that we produce music. There is contempt because of the name 'Roma'. People are afraid when we are mentioned. But, as I said, there are differences among the Roma. There are basket makers, broom makers, and blacksmiths. But we are musicians, 
we are different. We play for celebrities all over Turkey." (RM7, Group Interview with 4 male participants, Musicians Association).

The construction of the self therefore can be seen to emerge in reaction to the initial exclusionary spatial practices and discourses of the locals. Contrary to the self-construction of the locals through othering, the Roma population initially focuses on two of their characteristics: music for men and honor for women, in their response to negative discourses and practices. While this contributes to the formation of the self, they further illustrate their unique characteristics such as being fun and the ties they have with each other. While acknowledging that there is truth in some of the negative aspects, such as having low grades at school, they suggest that the reason is due to their profession. On the other hand, they do differentiate themselves from the other Roma communities.

The Turkmens: Iraqi Turkmen construct Demirlibahçe in a similar way to the Roma. The difference is that the initial Turkmens who arrived in the neighborhood did not face exclusionary practices. On the contrary, their status as being forced migrants and their 'Turkishness' were initially welcomed with positive discourses by the locals. However, when their numbers increased, the discourses became more negative, and this affected their construction of the self and the other.

The Turkmen residents generally say that the reason they originally came to the neighborhood of Demirlibahçe was only because their relatives either previously visited or stayed there before ISIS took over Telafer in 2014 (Chulov, 2014). Their main motivation was therefore to move to a place that was already familiar to them. Another attractive feature was that the rents are affordable compared to other central districts of Ankara due to the old housing stock. Turkmen residents also often rate Demirlibahçe highly for being close to the center, hospitals, and schools.

In their construction of the neighborhood, reference is made to their previous life in Telafer. The main emphasis is on the sizes of the houses, village life, and working conditions. The participants lamented that they had massive houses in Telafer in which the whole family; grand- parents, parents, children, and grandchildren could live, whereas in Demirlibahçe, they no longer feel the freedom they experienced and consider their new houses as being like a modern jail. ${ }^{12}$

"The houses were so large. Oooo... You could get a tank inside. We are in a cage here, I swear. We used to sleep on the roofs there in the summer. Here, there are a lot of people, but we are not used to a crowd. Now most Turkish friends here complain about our Turkmens. Why is that? Because of the noise. We are not used to houses that are next to each other, like they are here, where the sound goes straight through. In our Iraq, the sound was not heard in houses with 6-7 rooms, 2 or 3 floors and in the houses with gardens." (IR2, Male, 1976, Restaurant owner, Uzgörenler St.).

Currently, Turkmens appropriate their own spaces in Doğanbahçesi and Ağaçlı St. Similar to the Roma population in Demirkapı St., they feel attachment to these particular streets. As the neighborhood is inhabited by those who belong to the same tribe coming from Telafer, they have their own labeling when talking about each other. While Doğanbahçesi St. is called Baghdad St., the neighborhood is called Hasanköy.

However, not all of the Turkmens are missing their homes in Iraq. Contrasting their efforts for integrating themselves into society, as opposed to other Turkmens who do not even try, the Turkmens also differentiate themselves in a way that would not produce exclusionary discourses from the locals. In other words, they construct themselves as being hard working, original Turks, and keepers of Islamic traditions.

"I never thought of going to another country. Because we are already Turkmens, we came here. We always had a sense of belonging to Turkey. We also had Turkmen fronts in Iraq. After Saddam fell, fronts were established in 2004." (IR1, Male, 1991, second-hand phone business, Uzgörenler St.).

The Iraqi Turkmen construct their own other in order to fully form their identity. This is done by referring to the perceived immoral practices of the locals and the Roma; namely how ties have been broken with the Islamic traditions. The Turkmens often feel that the locals have

12 The term "modern jail" is also a term used to refer to the brutal gentrification processes that occurred in Ankara (Erman, 1997, p. 98) 
H.O. Karayiğit, Production of Space and Social Cohesion: Roma, Iraqis, and Locals in the Ankara Neighborhood of Demirlibahçe

become disassociated from traditions like hospitality and celebration of the religious holidays. A 16 year old participant at the Association even told me that he wants to return to Iraq because people are not practicing Islam in Turkey.

Furthermore, architecture-as-practice (Lefebvre, 1991, p. 272) impacts the production of negative perceptions, especially by the locals. To apply Lefebvre's notion, intervention by way of construction occurred in Demirlibahçe with two recent construction projects - renewal of the primary school and destruction of the bridge connecting Doğanbahçesi St. to Demirkapı St. These two projects had a negative effect for the locals on the political economy in the following years, and so exacerbated the negative discourses.
School renewal projects were carried out in multiple locations within the Mamak districts. The map below marks the location of these renovated schools with red squares (Figure 8 ). While historic primary and secondary schools were demolished in 18 locations out of a total of 70 (excluding 19 in the peripheries), the case of Demirlibahçe Primary school was particularly controversial. Following the Strategy Plan of 2015, which covered a 4 year vision that was to be actualized in 2019 (Stratejik Plan, 2015-2019, p. 9), the school was demolished after completion of its 2016-2017 curricular year (Figure 9). The students and the teachers were moved to Nazım Berger Primary School for two years until the new building was completed on 27 March 2019, as per the official occupancy permit. However, the demolition of the school
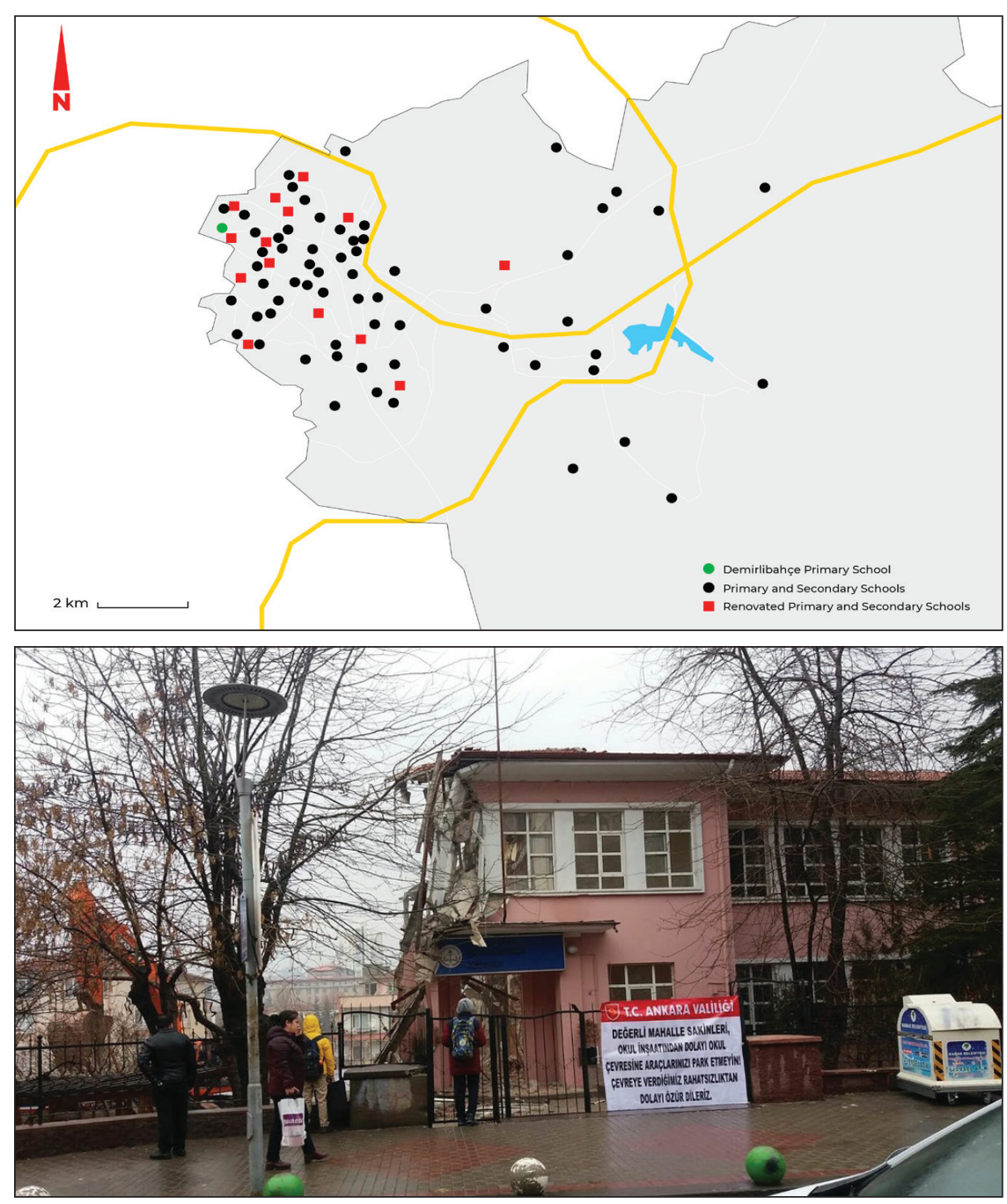

Figure 8. Map of the renovated schools in Mamak District, excluding those in the peripheries.

Source: Created by: Hakkı Ozan Karayiğit; Design: M. Gürkan Gürler.
Figure 9. Destruction of the Demirlibahçe Primary School as watched by students and passers-by. Source: Demirlibahçe Facebook Groups. 
not only affected the economy of the neighborhood, but also the sense of belonging of the locals, many of whom graduated from the school.

"That school should not have been destroyed. Even my father studied there. Of course, we look at the situation with nostalgia. Nowadays, most people do not send their children there anymore because there are way too many Turkmens." (TR20, Male, 1968, Real-estate Agent, Uzgörenler St.).

Based on the perceptions of the spatial practices that each group has towards each other; it can be concluded that there is a low level social cohesion in the neighborhood. As the locals construct the self as a way of differentiating from the others, exclusion is seen as a necessary factor for preserving their identity (Gür, 2002; Richardson and Jensen, 2003). While the exclusionary perceptions of the Roma and their spatial practices were reproduced through judgement of their life-styles, these exclusionary perceptions subsequently became positive discourses when faced by the newcomers, namely the Turkmens, after 2014. The Roma, on the other hand, do not have particular negative sentiments in their perceptions towards the other with regard to the arrival of the migrants. Apart from the feeling of being devalued compared to the migrants, they have their own sense of cohesiveness in Demirkapı St. However, this feeling of being devalued in relation to their perception of the spatial practices of the immigrants contributes to the reshaping of social cohesion between the locals and the Roma, as the two groups are united in their Turkish citizenship. The Turkmens, for their part, perceive the neighborhood as their own by claiming its specific locations in their discourses. It can therefore be said that the Turkmens self-integrate themselves into the local community by emphasizing their Turkishness, while differentiating themselves from the Roma. While the locals hesitate to acknowledge their ethnicity, they do recognize the Ottoman roots of the Turkmens. Table 3 below sums up the discourses that each group directs towards each other.

\section{ii. The Conception of Space and Political Economy in and of Demirlibahçe}

The construction of Demirlibahçe by the inhabitants has a mutually constitutive relationship with the exchange value of the neighborhood and the political economy within it. The political economy of the neighborhood refers to its exchange value and representations that are conceived through its distance to the central areas of Ankara and its subjects ("elites," "gypsies," and "migrants"). Affecting the political economy in the neighborhood, the spatial practices of inclusion and exclusion are facilitated and exacerbated by interventions (renewal of the school and demolition of the bridge) that manipulate the networks of exchange.

This section utilizes Lefebvre's proposition for examining the space with its parts and its whole (implication and explication), to examine the entire conception of Demirlibahçe. The political economy of the neighborhood in this regard is read through the impact of sociospatial transformations on the exchange value of fixed capital, and thus the exclusionary discourses. Resonating with the theory of centrality, the concentration points of each group impact how the neighborhood is represented. For the Roma, Demirlibahçe is seen as place of musicians, whereas it is Hasanköy for the Turkmens. However, the locals no longer consider it a place for the elite. Thus, the changing conception by the neighborhood serves to exploit the disadvantaged groups in terms of real-estate prices. In other words, the political economy of the neighborhood is instrumentalized to use space as the medium of segregations.

However, this apparent shattering of neighborhood space is actually unified on the basis of the commodity exchange that effectively erases the differences. Hence, a second purpose of this section is to minutely examine the political economy in Demirlibahçe through the networks of commodity exchange. While exclusionary practices are reproduced by the owners of fixed capital in voicing their loss in exchange values, political economy in the neighborhood becomes the anchor for social cohesion. Social cohesion of this type persists until the hierarchical relationships are sustained, and thus results in a greater social capital for each group.

\section{The Political Economy of Demirlibahçe}

The conception of Demirlibahçe refers to the neighborhood's exchange value through its representation. The exchange value of the neighborhood is measured by quantities such as its distance to public transportation, density of commercial places, and the commodity quality of the housing.

The renovation of the school and the demolition of the bridge as part of the Başkentray project (Uysal, 2016) can 
Table 3. An Overview of the Perceptions Each Group Has of Each Other (Irregular Talks Are Also Integrated)

\begin{tabular}{|c|c|c|c|c|c|}
\hline \multicolumn{2}{|c|}{ Locals } & \multicolumn{2}{|c|}{ Iraqi Migrants } & \multicolumn{2}{|c|}{ The Roma } \\
\hline Positive & Negative & Positive & Negative & Positive & Negative \\
\hline $\begin{array}{l}\text { They are our } \\
\text { Turkmen } \\
\text { brothers and } \\
\text { sisters, we } \\
\text { should help. }\end{array}$ & $\begin{array}{l}\text { They are not } \\
\text { Turks. No Turk } \\
\text { flees from a war. }\end{array}$ & $\begin{array}{c}\text { We are also } \\
\text { Turks. We } \\
\text { speak the } \\
\text { same Turkish } \\
\text { language in Iraq. }\end{array}$ & $\begin{array}{l}\text { The most resilient } \\
\text { Turk here cannot } \\
\text { survive for one day } \\
\text { in Iraq. }\end{array}$ & $\begin{array}{l}\text { We do not } \\
\text { differentiate } \\
\text { human } \\
\text { beings. }\end{array}$ & $\begin{array}{l}\text { They (Iraqis) are the } \\
\text { traitors. The sources } \\
\text { of the country are } \\
\text { spent on them. They } \\
\text { even have their own } \\
\text { businesses here. }\end{array}$ \\
\hline \multirow[t]{3}{*}{$\begin{array}{l}\text { We all share } \\
\text { a common } \\
\text { Ottoman past. }\end{array}$} & $\begin{array}{l}\text { We are more } \\
\text { civilized. They are } \\
\text { culturally } 50 \text { years } \\
\text { behind us. }\end{array}$ & $\begin{array}{c}\text { We are from } \\
\text { the Ottoman } \\
\text { heritage. }\end{array}$ & $\begin{array}{l}\text { Turks' loyalty to } \\
\text { Allah is corrupted. } \\
\text { They have forgotten } \\
\text { about their culture } \\
\text { and tradition. }\end{array}$ & $\begin{array}{c}\text { We are all } \\
\text { Ottoman and } \\
\text { Turkish. }\end{array}$ & $\begin{array}{l}\text { I cannot let my kid } \\
\text { go out to the streets. } \\
\text { Why would I? So } \\
\text { that the Iraqis can } \\
\text { rape them? }\end{array}$ \\
\hline & $\begin{array}{l}\text { They smell, } \\
\text { they talk loudly, } \\
\text { and block up } \\
\text { the streets by } \\
\text { gathering in large } \\
\text { groups. }\end{array}$ & $\begin{array}{l}\text { May Allah bless } \\
\text { the Turks; they } \\
\text { opened their } \\
\text { doors to us. }\end{array}$ & $\begin{array}{l}\text { Not all the } \\
\text { Turks are the } \\
\text { same (leftists vs } \\
\text { rightists). Some } \\
\text { of them do not } \\
\text { even like their own } \\
\text { people. }\end{array}$ & $\begin{array}{l}\text { They are } \\
\text { making their } \\
\text { own fight to } \\
\text { survive. }\end{array}$ & $\begin{array}{l}\text { It bothers us a } \\
\text { lot when we see } \\
\text { the migrants are } \\
\text { welcomed while we } \\
\text { are neglected. }\end{array}$ \\
\hline & $\begin{array}{l}\text { They think their } \\
\text { women are only } \\
\text { for reproduction. }\end{array}$ & & $\begin{array}{c}\text { Our women pay } \\
\text { attention to their } \\
\text { honor, unlike the } \\
\text { Turks. }\end{array}$ & $\begin{array}{c}\text { I love } \\
\text { my Iraqi } \\
\text { neighbor's } \\
\text { son. He is } \\
\text { also my son. }\end{array}$ & $\begin{array}{l}\text { They are extremely } \\
\text { dirty and smelly. }\end{array}$ \\
\hline $\begin{array}{l}\text { The Roma are } \\
\text { fun people and } \\
\text { talented. }\end{array}$ & $\begin{array}{c}\text { The Roma people } \\
\text { make too much } \\
\text { noise. }\end{array}$ & $\begin{array}{l}\text { We have no } \\
\text { problem with } \\
\text { the Roma, some } \\
\text { of them are our } \\
\text { customers. }\end{array}$ & $\begin{array}{c}\text { They act free } \\
\text { sexually. Are they } \\
\text { not Muslim? }\end{array}$ & $\begin{array}{l}\text { We are all } \\
\text { citizens of } \\
\text { this country. }\end{array}$ & $\begin{array}{l}\text { Those who consider } \\
\text { themselves better } \\
\text { than us, what } \\
\text { contributions } \\
\text { they have made to } \\
\text { country? Do we not } \\
\text { have value like the } \\
\text { Iraqis? }\end{array}$ \\
\hline $\begin{array}{l}\text { Roma culture } \\
\text { has value. }\end{array}$ & $\begin{array}{l}\text { Their culture is } \\
\text { different, and they } \\
\text { do not contribute } \\
\text { to the society. } \\
\text { They are more } \\
\text { idle. }\end{array}$ & $\begin{array}{c}\text { We share } \\
\text { a similar } \\
\text { experience of } \\
\text { being excluded. }\end{array}$ & $\begin{array}{l}\text { They have a hostile } \\
\text { attitude towards us. }\end{array}$ & & $\begin{array}{c}\text { Can the locals work } \\
\text { under the conditions } \\
\text { we work? They do } \\
\text { not even know about } \\
\text { music; how dare } \\
\text { they ignore us! }\end{array}$ \\
\hline
\end{tabular}

be read as an attempt to increase the exchange value of the neighborhood. However, by causing the real-estate prices in Demirkap1 St. to decrease by detaching the street from other parts, the planned space has assigned "special status to particular places by arranging them in the hierarchy, [thus] stipulat[ing] exclusion (for some) and integration (for others)" (Lefebvre, 1991, p. 288).

For the locals, the exchange value of the neighborhood has decreased, due to the interventions of construction that caused the elites to leave. Furthermore, the arriv- 
al of the Turkmens is seen as the major factor which decreased the value of the neighborhood. However, the demographic transformation of the neighborhood is not only caused by the Iraqi Turkmens, as the presence of the Roma population is also a topic of concern for the political economy. As the Roma population around the world is characterized by racial judgements based on accents and physical appearance, they are considered to have 'tendencies' in terms of illegal activities such as stealing and pickpocketing. This Romaphobia (Ljujic, Vedder, Dekker and van Geel, 2012) affected the exchange value of the neighborhood of Demirlibahçe by creating a 'bad' representation.

"It's over, Demirlibahçe is over. Think about it. 5 years ago I could buy a place in central Ankara by selling my flat for 250 thousand and adding 150 thousand. But the prices in the place where I would want to buy have increased from 400 thousand TL to 800 thousand. Here, prices are not increasing, they are decreasing, because the quality is over here. The Roma are over there down the road and the Iraqis above. We are thinking of ending our professional life here and leaving." (TR26, 1976, Barber, Ağaçlı St.).

Data taken from Hürriyet Emlak (a real-estate portal) supports this changing conception of the neighborhood. As seen in the demography graphic (Figure 3 ), the decrease in sale price for housing correlates with the decrease in the neighborhood population between July $2018-2019$. However, rental prices increased during the same period, even more than the Ankara's average. While the prices in a close neighbor, Cebeci, have increased only gradually from around $9 \mathrm{TL}$ per $\mathrm{m}^{2}$ in July 2014 to around 12 TL per $\mathrm{m}^{2}$ in July 2021, the rental prices in Demirlibahçe have skyrocketed since 2014 from around 7 TL to around $11 \mathrm{TL}$ per $\mathrm{m}^{2}$. In contrast, selling prices have actually decreased significantly between July 2018 - 2019 (Figure $10 \mathrm{~A}$ and 10B; Figure 11A and 11B).

These periods of increases and decreases in rental and selling prices correlates with the construction process of the new school and bridge. However, these interventions caused the locals to move out from the neighborhood and thus created space for the newcomers. The graphs below show that the arrival of the Turkmens has been of the most benefit to homeowners. By creating an increased demand for rentals, the Turkmen population has been seen as a source of income, and compensation for the decrease in Demirlibahçe's exchange value as a neighborhood in the selling market. Although the locals generally consider their space as being threatened by Roma and Iraqi immigrants, they on the other hand benefit from them, particularly the Iraqis, due to the exploitation of the housing prices and the use of the space as a tool of power.

"Yes, they were renting from us, but we are not responsible for this, the owners are. Because we do not have the right to have a say in someone else's home. If the owner says give somebody the house, then we do. The landlords have given up the houses, and now they regret it." (TR20, Male, 1968, Real-estate Agent, Uzgörenler St.).

"Now people beg us to sell their houses to whomever buy them, but are the real estate agents responsible for this situation? Not at all. We tried to give them to decent people as far as possible, but the owners demand money." (TR28, Male, 1965, Real-estate Agent, Uzgörenler St.)

While the locals' conception of the neighborhood is concerned with its decreasing exchange value, the Roma population views Demirlibahçe as a sign of their rising status. Indeed, the Roma population is not actually concerned about the political economy of the neighborhood in terms of its exchange value. As they have already claimed their own place, they are satisfied with the representation of Demirlibahçe as a neighborhood of musicians. Earning their livelihood by working in places outside the district, such as in pavilions and restaurants, the musicians see Demirlibahçe as being their center.

"Now there is such a perception in Ankara. Let's say you are working in a place or having a coffee somewhere. When they ask where you live and you say Demirlibahçe, they say "Oh, the musician neighborhood." People see it like that. When people think of Demirlibahçe, musicians come to mind." (RM7, Group Interview with 4 male participants, Musicians Association).

Therefore, the political economy of the neighborhood is shaped by the two socio-spatial factors that have changed the texture of Demirlibahçe, and thus its exchange value. On the spatial side, three factors are significant: separation from the Çankaya District and inclusion in the Mamak District in 1983, closure of Muallim Mektebi and the movement of Mamak municipality in 2005 to its current place, and the renewal process of the primarysecondary schools and the bridge in 2017-2019. On the social side, mobility patterns of the three groups were 

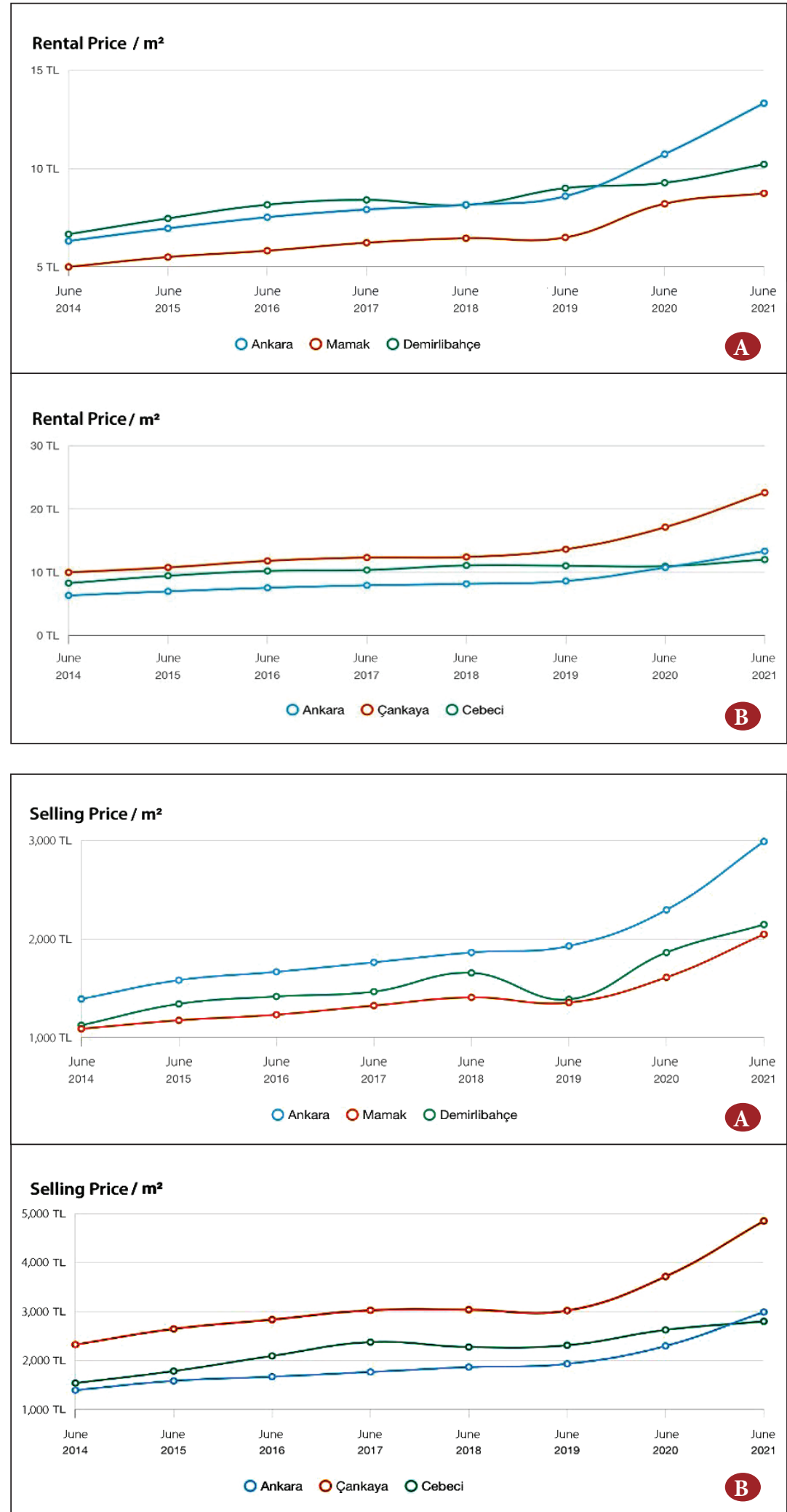

Figure $10 \mathrm{~A}$ and 10B. Rental prices for housing in the neighborhoods of Demirlibahçe and Cebeci.

Source: Hürriyet Emlak, July 2021.
Figure $11 \mathrm{~A}$ and $11 \mathrm{~B}$. The selling prices of houses in the neighborhoods of Demirlibahçe and Cebeci.

Source: Hürriyet Emlak, July 2021. 
significant: the movement out of the district of the high bureaucrats towards the suburban areas in 1980s-1990s, and the inflow of the Roma (1990s) and the Turkmens (2014). In conjunction of these socio-spatial transformations, the political economy of the neighborhood is instrumentalized to use space as the medium of segregations. While the owners of fixed capitals benefit from the situation through increased demand for rentals, abstract space is served to profit them and assign negative status to particular places. Hence, Roma's Demirkapı St., and the Turkmens' Doğanbahçesi and Ağaçlı St., are represented as being causal factors in the decrease of the neighborhood's exchange value.

\section{Political Economy in Demirlibahçe}

Lefebvre proposes two converging approaches for examination of the space in both its parts, and as a whole, to reveal how representation of space affects the quality of the space. In the previous section, the neighborhood space was elaborated in its entirety; along with how its exchange value is measured by the quality of the housing, while distance to the city center is considered for spatialanalysis.

Within the framework of political economy in Demirlibahçe, the intention is to illustrate how parts of the space are abstracted. Explaining the concept as being the "new capacity for concentration" (p. 334), Lefebvre defines centrality, whether mental or social, as "the gathering together and meeting of whatever coexists in a given space" (p. 331). As a form, centrality is also movable. Furthermore, as new capacities for concentration can emerge, there can also be multiple centralities differing in scales and sizes. Diverging from the conventional understanding of urban being composed of the center and peripheries, Lefebvre asserts that "complete urbanization of society" (2003) leads to the massive dispersal of centralities with differing urban hierarchies on a planetary scale (Schmid, 2018, p. 604).

Leading to the concretization of social capitals for each group, scale-making practices (Smith, 2008, p. 180) facilitate and exacerbate social cohesion and exclusion. Exclusion is exacerbated because the increasing capacity of a social capital for one group stimulates the economy for itself and by itself. However, this circulation is not marked by boundaries that prevent commodity exchange with others, but also contributes to the entire economy of the neighborhood.
Struggling for hegemony over the political economy of the neighborhood, the locals first exploit the housing sector in collaboration with real-estate agents. Although real-estate agents vindicate themselves on the basis of not interfering with the preferences of homeowners, the participants in this research have had at least one Turkmen employee, except one real-estate agent (TR7, Female 1977, Real-estate Agent, Uzgörenler St.). These Turkmen workers, who can speak Turkish and Arabic fluently, helped the real-estate agents to attract Iraqi migrants searching for a place in Demirlibahçe close to their relatives. With the approval of the home-owners who were satisfied by the Turkmens paying their rents on time, the profit acquired from immigrants, whose lack of knowledge of the housing market was being rather exploited, was almost doubled.

"Let me say this; these citizens rent even the dilapidated houses in this district, and kept the idle shops going on the extension of the street (Uzgörenler St.). While the owners could not find tenants for 50 or 100 liras in the past at the back of the street, they now are sold for the same price as the ones here that looking at Çankaya, because there is constant demand." (TR8, Male, 1975, Shopkeeper, Uzgörenler St.).

"Realtors were ultimately driven by the idea of making money. These people were coming here in droves, and there was lots of money to be made. In the end, the realtors would earn $2.5 \%$ from each rent, or even part of the rent. That's a good amount. How did realtors use it? They convinced the owners to rent the apartments by saying that the incomers are from a good family, there are not that many of them, and so on. Also, when 9 out of 10 incomers were Iraqi, they surely increased their money. Realtors saw they could go up to $800 \mathrm{TL}$, not $500 \mathrm{TL}$. When they came here, they also made serious profits. The only thing that is damaged here is the neighborhood culture." (TR 27, Male, 1986, Contractor, Ağaçlı St.).

After the dilapidated places had been occupied, the locals tended to focus upon the positive aspect of having a cosmopolitan and diversified neighborhood while overlooking the negative discourses that arose from their perception with humanitarianism. In other words, the benefits of the Turkmens being part of the political economy in the neighborhood are emphasized.

"Look, they (Turkmens) are very loyal about money. For example, they are very good at paying their rent. We've 
had no problems with $80-90 \%$ of tenants. Also, when I'm showing a house with Turkmens living in it, they always invite us in and offer us and the customer tea." (TR20, Male, 1968, Real-estate Agent, Uzgörenler St.).

"If you ask me, "do you prefer Turkish or Iraqis in terms of customers," I prefer Iraqi. That's because there is no lying, no credit card, no bargaining... they just give you whatever price you ask for. There is a lot of bargaining with our Turks. You agree on 300 TL, but they say they will not pay more than 150 TL and run away. That's it." (TR24, Male, 1989, Women Hairdresser, Ağaçlı St.).

Due to the necessity of making money, the locals, and especially the shop owners, overlook identity based perceptions. While the spatial practices of the other are perceived as being threatening, the political economy in the neighborhood erases the differences. In the capitalist system, the relationship between the buyers and the sellers connects them together. However, this connection does not necessarily represent progress towards social cohesion. Although it is indicated in the surveys that Turkmen participants are very keen on working with the Turks, this data is not representative of the overall social cohesion between the two groups, as it is actually acts of exploitation.

Hence, when the migrants start to run their own businesses, escaping the exploitative market conditions run by the locals, exclusionary practices are reproduced. While this process, beginning with the exploitation of fixed capital, has led to the emergence of different centers in the neighborhood for the two groups, the very same process is hidden on the basis of increasing social capital. When considering their two centers, it can be seen that the political economy in Demirlibahçe is now being shared by the Roma and the Turkmens.

The involvement of the Turkmens within the political economy does not emerge due to a deliberate intention to have a different center. Indeed, their appropriated spaces do not refer to a ghetto or enclave (Savran and Sat, 2019; Kavas, Avşar, Kadkoy and Bilgiç, 2019). That said, the emergence of the centers does automatically reduce the amount of financial activity that is made available to the locals since each group tends to be more trusting of other members of that group.

"We wanted to do business with the Turks, but then a scammer appeared and stole my money. Whoever wanted to start a business with us tried to scam us. We've had a lot of this. His father for example (points to the one Turkmen teenager working for the Association). He gave 16 thousand TL for a husbandry business. The scammer buttered up his father and his father also gave him money. Then he took all of the money and disappeared. We are still looking for it. This has happened to a lot of our people. They have been exploited by the Turks. For this reason, we now open our own shops and wait to see whatever our destiny will be." (IR13, Male, 1956, restaurant owner, Ağaçlı St.).

The increasing share of the Turkmens in the political economy, and more specifically, their local businesses, is under strong pressure from the locals. On the tragic day when 33 Turkish Army soldiers were killed in the Syrian town of Idlib on 28 February 2020 (NTV, 2020), some of the locals went into the streets and protested against the perceived 'comfortable' situation of the migrants in Turkey. Indeed, I was at home when I heard "Our soldiers are being killed in f.. Syria while these m...f.... here are enjoying themselves."

"Last year, I remember Turkish soldiers were killed in Syria. That's why some Turks burned down foreigners' cars and shops in Demirlibahçe. I heard this from some other Turkmens. And I heard some Turks stopped foreigners in the street and said to them "What are you doing here? Go back to your country!" For this reason, my family and I always stayed home during that time as we were very afraid. I used to live in Bahçelerüstü. Such things never happened there, but they often happen in Demirlibahçe. If the economy improves in Turkey, such incidents won't happen anymore." (IR14, Male, 1982, PhD Student \& Civil Servant in Iraq, Demirkapı St.)

The Roma, on the other hand, s well as not having a commercial center of their own, they did not generally benefit from state aid amid the pandemic lockdown. Participants in the study often expressed their resentment at their sense of being neglected in relation to the Turkey's migrant populations. Complaining bitterly about the care and assistance projects provided to the Syrians and to other migrants, one musician claimed that the virus has cost him and his family more than 150,000 Turkish Lira (around 16,147 US dollars as of October 2021 currency rates) over 6 months due to the music venues being closed.

Reflecting upon the elitist characteristics of lockdown policies that are seen to have been designed to protect the 
upper classes, the interviewees unanimously criticized nation-wide regulations and rejected the health-related causes of COVID-19. On 15 January 2021, there was a demonstration in front of $\mathrm{CHP}^{13}$ headquarters by musicians from Demirlibahçe who protested against being unable to earn their living due to the curfew regulations and being forced to sell their instruments to survive (Fox TV, 2021).

Yet, the Roma population has established their own civil society organization - The Musicians Association. The aim of this organization is to aid in the achievement of a long standing goal of the Roma: to secure themselves and their rights in the social and economic spheres. With the intention of fighting against perceived social and cultural stigmatization and exclusion, the founding members ( $R M 7$ and RM10) of the organization expressed their determination to educate the new Roma generation and thus provide them with opportunities other than those provided by music.

Overall, spatial practices of immigrants enable them to establish their own centralities that concretize their claim of, and appropriation on, the neighborhood. However, this creates exclusionary practices by the Roma and locals. Further, through struggling with the peculiar working conditions that have been created by the Covid-19 measures, the preexisting social cohesion between the locals and Roma continues to be reshaped; positively on the perception side and negatively on the conception (economic) side. During my initial site visits around Demirlibahçe Primary school in October 2019, I was told by one of the school-teachers about a Roma parent who had started shouting about the Iraqi immigrants. The teacher tried to interrupt her, but was told by the Roma parent that "your government is to blame for our terrible situation. Why did the Turkish state allow them in!"

Locals are currently anticipating a gentrification project that will renovate existing properties and construct more expensive housing. It is generally felt that this project will enable the locals to get rid of the Turkmens (Göksu, 2020). ${ }^{14}$ Emergence of different centralities create cleavages in social capitals that cause political economy to become segregated. Although this segregation appears to be homogenized by the networks of commodity exchanges that abstract the identity differences of the subjects, the increased capacity of the Turkmens via The Ottoman Turkmens Association, as well as the commercial places, additional donations, and care provided to them by international organizations, has led to the distortion of social cohesion between the locals and the Roma.

It can therefore be seen that the political economy of the neighborhood has been utilized for excluding the Turkmens' share in the political economy in the neighborhood. Although inclusion is practiced through commodity exchanges and by irregularly employing the Turkmens, practices of migrants' place-making has led to the disruption of the preexisting social cohesion between the locals and Roma. The Roma perceives the immigrants as being a rival, and a cause of the degradation in their economic well-being, pointing to institutional efforts to protect the refugees, but not musicians. However, while they place themselves as part of the social and cultural life of the society, the Roma community in the neighborhood does not differentiate themselves. As their means of production depends on local sector, their desperate situation compels them to go along with the preexisting cohesion, which is merely reshaped on the exclusionary practices towards the migrants. However, as the exchange value of the neighborhood is ultimately consumed, the locals would prefer a total reset by way of gentrification.

The maps below (Figure 12) show the land-uses and the current phases of centralizations for the three groups, as well as the spatial transformations in the neighborhood in regard to the places appropriated by the immigrants, the locals and the Roma. The first map represents the commercial (red) and residential (green) parcels that each group appropriates. While the Turkmens own the areas marked with straight lines, the dots refer to the Roma's location. Parcels with no filled dots or lines indicate areas owned by locals. The second map below depicts the levels of visibility for the three groups, with the wideness of the roads being altered in order to reflect traffic density. Although the three groups agglomerated in specific parts of the neighborhood, the streets are heterogeneous in that there are no signs for ghettoization.

13 Main opposition party - Republican People's Party.

14 https://www.sabah.com.tr/ankara-baskent/2020/04/10/ya-kentsel-donusum-ya-kat-farki 
H.O. Karayiğit, Production of Space and Social Cohesion: Roma, Iraqis, and Locals in the Ankara Neighborhood of Demirlibahçe

They further illustrate the current phases of centralizations for three groups, as well as spatial transformations in the neighborhood with regard to the places appropriated by the immigrants, locals and the Roma. The maps below provide hints on how streets are lived by each group in the neighborhood of Demirlibahçe. Generally speaking, the locals are no longer actually present in the streets, but have largely been replaced by the Roma and
Turkmen populations. Through the method of exercising daily talks, the two groups have created their own places in which culture is demonstrated through symbols.

\section{iii. Lived Spaces of Contradiction, Culture and Symbols}

Lefebvre asserts that although abstract space has homogenizing characteristics "towards the elimination of exist-

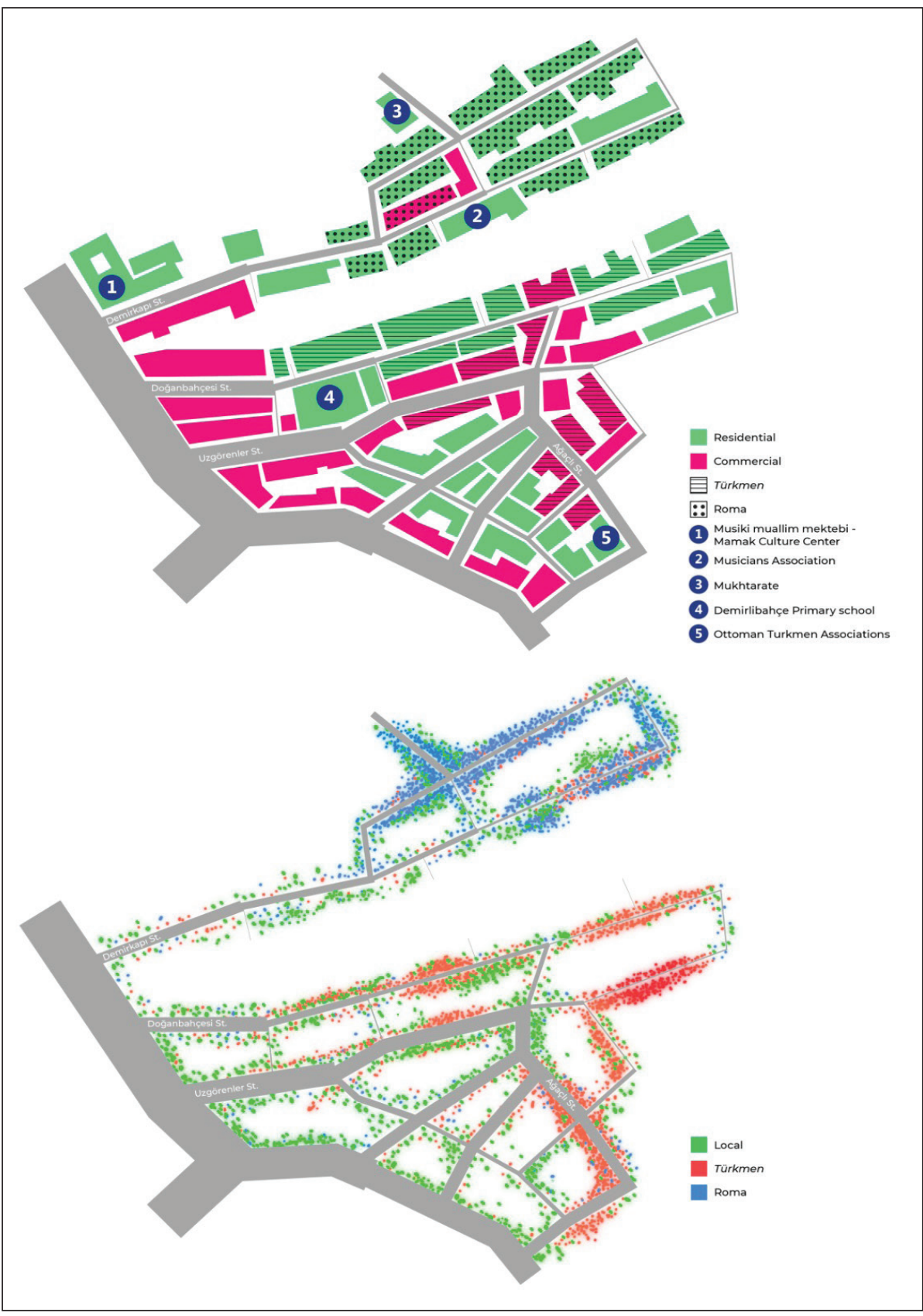

Figure 12. Maps that illustrate the centralization of three groups within four streets. Source: Design by M. Gürkan Gürler. 
ing differences or peculiarities" (p. 52), it also carries the possibility of the creation of new spaces. This contradictory character of the abstract space has been illustrated through the examination of different representations of Demirlibahçe by and for each group. These spatial contradictions express conflicts between socio-political interests and forces (p. 366). Yet, despite spatial contradictions are manifested in the neighborhood, they do not actually express conflict between socio-political interests and forces. By unintentionally establishing their own spaces, not a differential space, the Turkmen inhabitants have concretized their sense of belonging. These new capacities for centralization in Doğanbahçesi and Ağaçlı streets, however, "tends to annul rather than reinforce homogenization" since their involvement encompasses only producing things in space (Lefebvre, 1991, p. 390).

Indeed, these new spaces seem that the Turkmen and the Roma populations are capable of diverting homogenized space to their own purposes through utilizing "potential energies," (p. 391). In their use of streets, the Roma and Turkmen inhabitants deviate from homogenized space through their differences in culture, language, and ideologies.

Further, while lived space is experienced through the differing symbols and signs of the three groups, they seem to have their own unique characteristics within the appropriated streets. Such a view on the spaces of Roma and the Turkmen would demand the operationalization of the concept differential space, as their spaces would be intentionally produced against the capitalist accumulation and political domination. However, the differences are abstracted one more time as being "a coherent system that is partly artificial and partly real" (p. 376) in space through the mimesis of (neo-) Ottomanism. Combined with Islamist practices as the bonding element of society and a 'liberal' quest, ethnic differences are transcended and united under a common Muslim identity (Erdem, 2017, p. 715). Aligned with neo-liberalism, the cultural life of the society is governed on the basis of market and neoconservative rationalities (p. 719). While this allows, and encourages, individuals to join the market, they are also required to comply with a set of moral-religious rules. Hence, it is not differential to see the symbols of Ottoman flag in front of commercial shops as inhabitants are well-informed about ruling party's political agenda in defining the nation.
Lefebvre indicates in this regard that differences "endure or arise on the margins of the homogenized realm, either in the form of resistances or in the form of externalities" (1991, p. 373). However, those margins of the homogenized realm (Doğanbahçesi St., Ağaçlı St., Demirkapı St., and the rear parts of Uzgörenler St.) establish their own centralities that change the representation of Demirlibahçe. While "the existing center and the forces of homogenization must seek to absorb all such differences," (Lefebvre, 1991, p. 373) imposed ideologies of neo-Ottomanism further "fails to acknowledge the ethno-religious differences and the demands for cultural rights of its citizens" (Erdem, 2017, p. 715-716).

The neighborhood is therefore homogenized into a neoOttomanist way of life. Imposed by the ruling party's agenda in defining the nation (Batuman, 2017), individuals with different ethnic and cultural backgrounds are represented in the same way under neo-Ottomanist mimesis. Following this ideology that considers other Turks as being the same as the ones in Turkey (Batuman, 2010), the Turkmen migrants are seen as distant relatives. While neo-Ottomanism and Turkishness dominate the fragmented neighborhood space, the spaces of inhabitants are excluded based on the perception and conception of the neighborhood. Therefore, the third concept of social space, representational space, is operationalized to illustrate the spatial struggles and common features that exist among the habitants. While cultural differences are homogenized through neo-Ottomanism, this process of representational space creates different formations of social cohesion on the basis of political agenda, and thus diverges from the focus away from identity group formation.

By establishing their own spaces through spatial and social transformations, the lived space of the neighborhood becomes an arena of symbols and images that overplay the physical spaces of the three groups. These symbols and images are actually used by all the inhabitants as a strategy for (self-)integration, and thus to create unity with the abstract political nation-building propaganda within the spatial and social structure of the neighborhood. This is especially the case for Turkmens residents, who commonly display Ottoman flags and the Sultans' signatures in shops and commercial places. By thus symbolizing their rightful share in the production of space, the immigrants arrange their spaces through such representations. 
H.O. Karayiğit, Production of Space and Social Cohesion: Roma, Iraqis, and Locals in the Ankara Neighborhood of Demirlibahçe

These arrangements through symbols are also often achieved through the naming of the shops, such as Turkmens butchery, Mosul Restaurant, Mosul Barber Shop etc. Indeed, when I asked the Turkmen shopkeepers the reasons why they put the flags inside or in front of their businesses, they emphasized the 'fact' that they are Turkic, despite living in an Arabic state, Iraq (Figure 13).

"We hung the flags because we are racist, because we are Turkish. Our blood is Turkish. Now I wish you could see my son. He's more of a racist than I am. Turanian. I mean, it's in our blood, there's no need to lie. But I wish the people would understand how we feel here, or realize the persecution we faced in Iraq because of our ethnicity. We saw a lot of discrimination during Saddam's time. Let me tell you something, we didn't have political power then. There were villages smaller than Telafer. They became provinces, but Telafer did not. Why not? Because Telafar is 80\% Turk." (IR4, Male, 1974, second-hand phone business, Uzgörenler St.).

These attempts to self-integrate by the Turkmen residents are also supported and represented by the Ottoman Turkmens Association (Figure 14). Established in Demirlibahçe on 10 October 2018, the association receives funding from the Mamak Municipality, individual donors, the Turkish Red Crescent, and also the Directorate of Religious Affairs. While the naming of the association and its funders illustrate government-supported neo-Ottomanist institutionalization, it also contributes to the neo-Ottomanist mimesis.

"These are our Turkmen brothers and sisters who have Turkish blood from our Ottoman past. Look at the name, it's "Turk-men." They know history as well as we do. They also say, "After the Ottoman Empire collapsed, we stayed there. The Iraqis there called us foreigners because they are of Arab origin, but we are Turkmens." Of course, we have citizens who exclude them here too, but after all, they are Turkish and have Turkish blood. And besides, we are all Muslims. We have many things in common." (TR13, Male, 1971, President of Ottoman Turkmen Association, Ağaçlı St.).

Islamist culture, Ottomanism, and Turkishness are therefore used as a tool for the social cohesion of the three groups, despite their actual differences in ways of lives. In order to counter these stigmatizing and exclusionary practices, the Roma population also favors this tool to comprehend the Turkmens by perceiving them as a group who is ethnically and culturally similar, and that a similar practice of self-integration is actually applicable to them. In other words, by seeing themselves as a part of Ottoman heritage, the Roma population extends Turkishness beyond mere citizenship. In order to provide a location for themselves in this mimesis of nationhood, the Roma sees the Iraqi Turkmens as having a similar problem to the one they used to face.

"Iraqis are actually Turkmens. I wouldn't call them Iraqi. In fact, because they are misrepresented, problems arise.

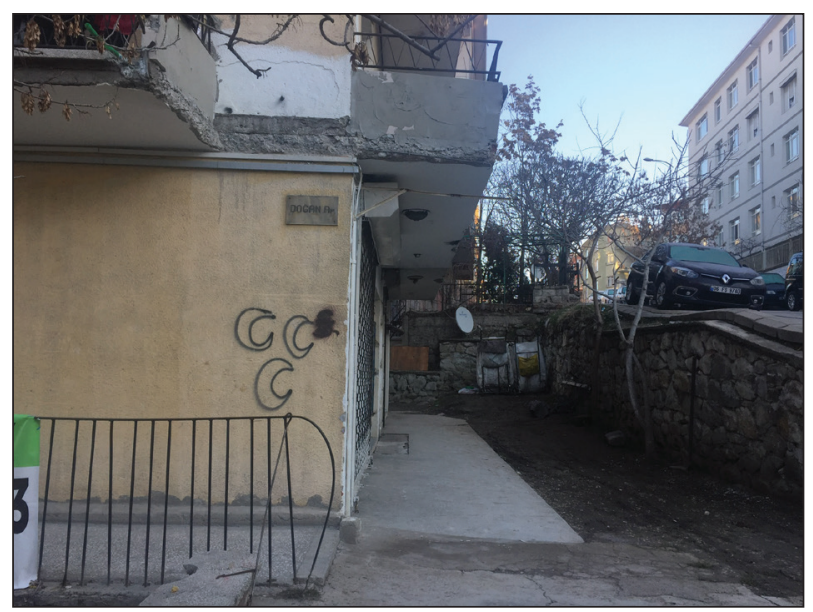

Figure 13. Three crescents in the façade of an Iraqi barber shop. The three crescents were used in Ottoman era, and it is now the logo of the Nationalist Movement Party (MHP) as a symbol of Turkish nationalism.

Photograph by: Hakkı Ozan Karayiğit, 9 October 2020.

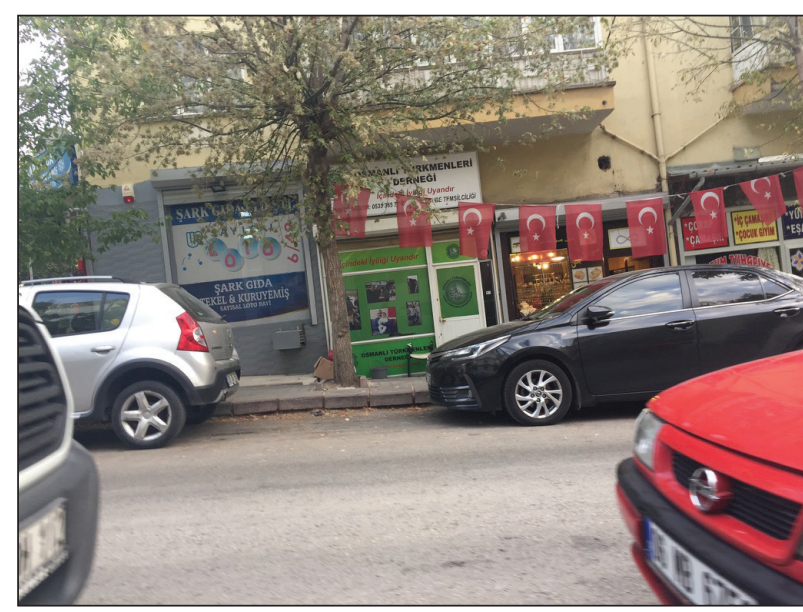

Figure 14. Façade of the Ottoman Turkmens Association. Photograph by: Hakkı Ozan Karayiğit, 9 October 2020. 
People think they are Syrians. Someone needs to come out and stress that these people are Turkmens, they are one of us. Of course, there were troubles before, but now there are none. The thing is all oppressed communities live in crowds because they are afraid. I see even the children banding together. In order to prevent this, it should be stated that these people are Turkish and, along with us, are part of the same mosaic." (RM9, Male, 1986, Musician, Demirkap1 St.).

While this mimesis of neo-Ottomanism and Turkishness is symbolized voluntarily by the Turkmens, it also seems to be approved by the locals and the Roma. Leading to the connectivity between the spaces of centralization of each group, the symbols have become the main unitary factor that cover differences in the perceived space.

However, although this mimesis of neo-Ottomanism and Turkishness is symbolized in order to homogenize the differences, the space lived in is actually not cohesive in the neighborhood of Demirlibahçe. This is because while these symbols are facilitated through a dominant political agenda, the differences are not apparent. Indeed, the display of flags and the signature of sultans refers to the production of the reproducible. Therefore, by aligning with the hegemonic political power of the ruling party (AKP), "the production of space is thus transformed into its opposite: the reproduction of things in space" (Lefebvre, 1991, p. 377). In other words, turning this mimesis into a reproduceable imitations, the adoption of neo-
Ottomanism leads to the renewal (or reproduction) of existing social relations (p. 377).

Moreover, the spaces of the Roma and the Turkmens do not actually constitute a struggle for space that can be called as differential space. Their efforts for political and economic representability that is integrated in the existing hegemonic power does not constitute a spark for urban right movement. Rather it is the differences between the cultures, the symbolization of Ottoman past or the Turkishness, which fails to create cohesion in experienced space. As the locals see the cultural practices of the Roma (such as celebrating weddings in the streets - Figure 15 below) and the Turkmens (relationship between men and women) as being inferior to their own, the actual differences in the lived space emerge politically. It is in this regard that the production of space is revealed through spatial contestations for and against the dominant symbols and images of neo-Ottomanism.

Homogenization of differential spaces through neoOttomanist mimesis also leads to another exclusion in terms of women's bodies. By subsuming a cultural way of life in accordance with Islam, women are questioned on the basis of their social role and physical appearance in the streets. While on the one hand uncovered women are seen as evidence of a distancing from traditions, on the other hand their lower social role in the family is seen as a symptom of backwardness. This cleavage is reflected in Turkey's predicament of modernity between the Islamist

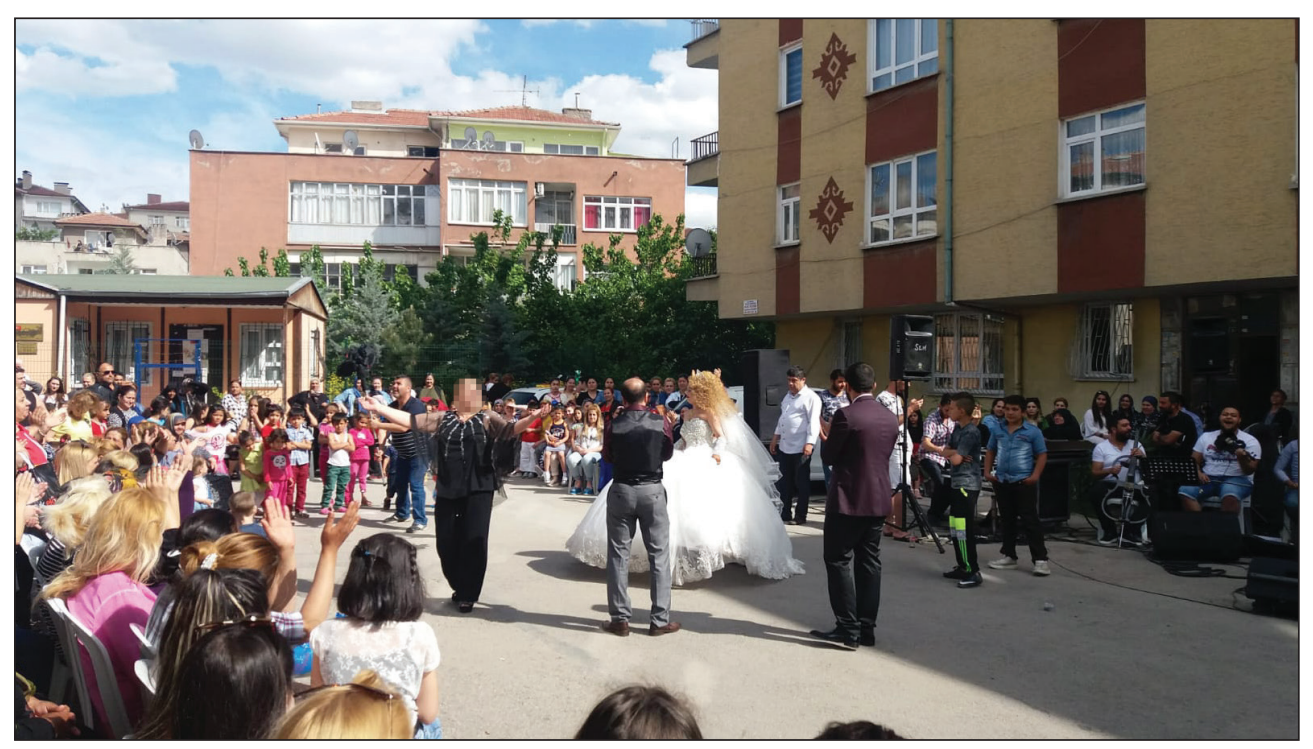

Figure 15. A Roma wedding in front of the office of the local community leader in Demirkapı St. Date unknown (presumably 2014-2015). Source: Mukhtar S. Hanım. 
versus secularists (Cınar, 2005; Bozdoğan, 1997). While the ideological diversities between the secularist and the Islamist is deepened with Islamist urbanism in the definition of the nation (Batuman, 2017), Turkmens are (self-) integrated into the Islamist side.

"The country belongs to the Republic of Turkey. We cannot say anything about it (women question). But whatever is secret, is more beautiful. After all, when you give a gift, you give it wrapped up. If it is covered, it looks beautiful, but if it is open, it is not beautiful." (IR13, Male, 1956, restaurant owner, Ağaçlı St.).

"It is taught to us at a young age because it is the teaching of our Prophet that girls should cover their heads. But there is a sense of libertarian in Turkey. There are principles brought by Atatür, although they are wrong principles in our opinion. For example, if you are fasting as a man, when a woman with a lewd dress passes in front of you, it also corrupts your worship." (IR10, Male, 2004, Men barber tyro, Ağaçlı St).

It has therefore been shown that the lived space of Demirlibahçe is reproduced through neo-Ottomanist symbols in which all three groups share a common identity. It is reproduced because the usage of such symbols does not correspond to what Lefebvre proposes as a possible sign of resistance against the dominating power of the abstract space. Instead of representing their own space, neo-Ottomanist mimesis is practiced under the hegemony of the ruling party. While it has been adopted for the creation of identity, others who do not follow the same ideological practices are portrayed as being exclusionists, though it is them and their spaces having been excluded. Therefore, although the neo-Ottomanist mimesis allows the three groups to have representation under one unitary form, it is actually assimilating. It is assimilating because differences are subsumed under the mimicry of Ottoman common subjecthood. For the exclusionary practices are now turned to be in between secularists and Islamists, each group and its members in the neighborhood inhabits an arena of contestation.

\section{Conclusion}

This research has explored the relationship between space and social cohesion in three areas - the perceptions of Demirlibahçe, the conception of Demirlibahçe and the political economy, and the lived space of Demirlibahçe.
The first section explained how the three groups construct Demirlibahçe, the self, and the other based on their perception of space and spatial practices. Combined with the intervention in the neighborhood by construction and renewal projects (Demirlibahçe Primary School and the Başkentray Project), the commonalities and differences perceived in spatial practices were organized (table 1).

The second section focused on the conception of space. Following Lefebvre's proposition to investigate how political economy is instrumentalized for the segregation of space, the research then focused on the exchange value of Demirlibahçe. By investigating the political economy in two perspectives - the political economy of and in Demirlibahçe - it was shown that owners of the fixed capital include the Roma and the Iraqi on the basis of exploitation. The political economy of Demirlibahçe refers to the neighborhood value within Ankara. Due to the immigrants and it being within the Roma area, the neighborhood has a bad reputation in the market, and this has led to a decrease in the selling prices and a high level of exclusion by the locals. Thus, the political economy in Demirlibahçe reveals how the networks of commodity exchange become a form of social inclusion through exploitation. Turning to the differing perceptions of the self and the other in terms of the relationships of buyers and sellers, it has been asserted the differences are subsumed under the homogenizing impact of the capitalist system. However, while these differences are homogenized within the abstract space, different centralities also emerge in different streets. This is why the Roma population calls Demirlibahçe a musicians' neighborhood, whereas the Iraqi Turkmen call it Hasanköy.

Finally, the usage of symbols and signs have been explored in order to reveal how inhabitants represent their own spaces and representational spaces. These symbols and signs are the usages of Ottoman flag and the signatures of sultans. The Turkmen residents use these symbols for self-integrating into the neo-Ottomanist nation building process of the AKP government. This nation-building agenda is defined through the combination of Islamist practices as the bonding element of societies with 'liberal' quests (Erdem, 2017). Thus, ethnic differences are transcended and united under a common Muslim identity. Aligned with neo-liberalism, the cultural life of the society is governed on the basis of the 
market and of neoconservative rationalities (p. 719). However, since this is imposed by the hegemonic political power, it is a mimesis, as defined by Lefebvre (1991) as being a function in the domination of space (p. 376). Hence, there is the establishment of an abstract 'spatiality' as a coherent system that is partly artificial and partly real (p. 376). However, this coherent system deviates from Lefebvre's concept of differentiality and right to difference. This is because the differences of the Turkmens and the Roma are voluntarily given up for the mimesis of neo-Ottomanism, and so the issue drifts away from the issue of social cohesion between the identity groups towards a political sphere. Through the neo-Ottomanist agenda imposed by the AKP government, those who are in opposition are differentiated. When observed through notions of the female body, differences are practiced over the clothes and attitudes of women.

The conclusions reached by this research give rise to tentative propositions. Although it is still incomplete, due to my unanswered efforts to reach out to Mamak Municipality for the establishment of public policies, this study suggests that the establishment of some form of neighborhood council within which the members of each group would be able to represent their rights and complaints. It is suggested that instead of each group merely striving to defend their own rights through exclusive civil associations (such as the Musicians Associations for the Roma in Demirkapı St. and the Ottoman Turkmens Association for the Turkmens in Ağaçlı St.), a representative body would be beneficial in the development of the neighborhood.

In their study, Schneekloth and Shibley (1995) explain the concept of placemaking for "doing neighborhood development" by looking at the case of the neighborhood of Roanoke in the US (p. 2). In addition to the exodus from the city in the 1960s-1970s due to deindustrialization, there was a general feeling among many citizens that the city government was not spending the taxpayers' dollars efficiently. The Roanoke Neighborhood Partnership was established in an area of diverse neighborhoods with radically different socioeconomic, racial, and physical characteristics. Utilizing a utopian approach, the aim of the Partnership was to declare that "we, a partnership of neighborhood people, backed by the resources of the public sector, volunteer organizations, and businesses, can identify and resolve many of the problems affecting the quality of life in our city." (p. 112). Through the Part- nership, the inhabitants have agreed to "create an open space for dialogue about place and placemaking through developing a relationship with place constituencies" (p. 6). Secondly, the Partnership works to promote and facilitate the development of certain places of interest. Finally, professional place-makers are invited for to support the framing of action.

There was one major event organized by Mamak Municipality on 23 August 2019 at the Mamak Cultural Center, which was attended by the district mayor, community leaders, various NGO presidents, UN representatives, academics, and Turkmen opinion leaders. I was unable to attend the meeting, but the workshop has a written record, including all of the transcriptions (Karadeniz, 2020). Consisting of three sessions, the workshop touched upon what has been done, is being done, and what should be done for future social cohesion with regard to the foreigners living in Mamak Municipality. Identifying the major problems (access to employment, profession, judiciary systems, health, education, sociopsychological support, and social services), the result of the workshop was a call for an all-inclusive effort, led by Turkmens themselves, to change their negative image by engaging within social work in their own localities (Karadeniz, 2020, p. 140).

It is evident that Mamak Municipality, with its center for the consulting and coordination of asylum seekers, was in close contact with other state and international governmental organizations, as well as the Turkmen Migrants, Refugee, and Asylum Seekers Solidarity Association and academics. The municipality also established the City and Civilization Academy for discussing the urbanization process of the Mamak district in late September (Mamak Belediyesi, 2020). Turkmens also have their own well-established organizational structures that provide solidarity and care for themselves. However, municipal efforts have now ceased (I did not receive any response to my calls from the Municipality regarding the social cohesion issues in Demirlibahçe). Furthermore, the same organizational structures of the Turkmens have exacerbated further exclusionary practices, especially in the sphere of political economy. In this scenario, the 'harmony' between the three groups is badly damaged as each group aspires for its own social capital. This situation favoring certain advantaged members causes further exclusion through exploitation, which is not based on differences in identity, but in social class and politics. 
Therefore, while the majority of the residents describe their dissatisfaction with the state and municipal level negations, the establishment of a neighborhood council would enable inhabitants to systematically gather and plan their own solutions at a grassroots level.

\section{Ethics Committee Approval}

Ethical approval was obtained for the study protocol by the decision, dated 2 November 2020 and numbered 28620816, of the Middle East Technical University Ethics Committee.

\section{References}

Agnew, J. (1994). The territorial trap: the geographical assumptions of international relations theory. Review of International Political Economy, 1(1), 53-80.

Akkan, B. (2018). Roma and representative justice in Turkey. Horizon 2020 Framework Programme of the European Union. ETHOS - Towards a European THeory Of juStice and fairness.

Aktaş, O. (2020). Ankara night clubs as a simulation space. Kent Akademisi / Urban Academy, 13(2), 293-304.

Akyüz, K., Akbaş, H. and Onat, İ. (2021). Evaluating the impact of Syrian refugees on fear of crime in Turkey. European Journal of Criminology, 00(0), 1-18.

Alanyalı, E. (Ed.). (2017). Mapping Syrian migration: migrant spaces in Ankara. Ankara: METU Faculty of Architecture.

Anderson, B. (1991). Imagined communities. London, New York: Verso.

Ara, B., and Yasun, S. (2016). The educational opportunities and challenges of Syrian refugee students in Turkey: temporary education centers and beyond. IPC - Mercator.

Ataseven, A. and Bakış, Ç. (2018). Türkiye'de sosyal uyum. Retrieved from https://ipc.sabanciuniv.edu/Content/ Images/Document/turkiyede-sosyal-uyum-56dc0e/ turkiyede-sosyal-uyum-56dc0e.pdf

Baban, F., Ilcan, S. and Rygiel, K. (2017). Syrian refugees in Turkey: pathways to precarity, differential inclusion, and negotiated citizenship rights. Journal of Ethnic and Migration Studies, 43(1), 41-57.

Batuman, B. (2010). The shape of the nation: visual production of nationalism through maps in Turkey. Political Geography, $29,220-234$.

Batuman, B. (2017). New Islamist architecture and negotiating nation and Islam through built environment in Turkey. New York: Routledge.

Bernard, H. R. and Gravlee, C. C. (1998). Handbook of methods in cultural anthropology. AltaMira Press.
Bertelsmann Stiftung; Eurofound. (2014). Social cohesion and well-being in the EU. Eurofound and Bertelsmann Siftung.

Blaikie, N. (1993). Approaches to social inquiry. Cambridge: Polity Press.

Bogardus, E. S. (1959). Social distance. Ohio: Antioch Press.

Bourdieu, P. (2008). The logic of practice. Stanford: Stanford University Press.

Bozdoğan, S. (1997). The Predicament of Modernism in Turkish Architectural Culture. In S. Bozdoğan, \& R. Kasaba (Eds.), Rethinking Modernity and National Identity in Turkey (pp. 133-56). Seattle: University of Washington Press.

Bozdoğan, S. (2010). From 'cubic houses' to suburban villas: residential architecture and the elites in Turkey. In C. Kerslake, K. Ökem and P. Robins (Eds.), Turkey'sengagement with modernity: conflict and change in the twentieth century (p. 405-424). London: Palgrave Macmillan.

Bray, Z. (2008). Approaches and methodologies in the social sciences: a pluralist perspective. In d. P. Donatella and M. Keating (Eds.), Approaches and methodologies in the social sciences (p. 296-315). London: Cambridge University Press.

Cankurtaran, Ö. and Albayrak, H. (2019). Suriye'den Türkiye'ye kadin olmak. Ankara: Merdiven Yayın.

Cantek, F. Ş. and Zırh, B. C. (2014). Bir semt monografisine doğru: Cebeci'ye bakmak. İdealkent, 11, 138 - 170.

Cassiers, T. and Kesteloot, C. (2012). Socio-spatial inequalities and social cohesion in European cities. Urban Studies, 49(9), 1909-1924.

Çelik, Ç. and İçduygu, A. (2019). Schools and refugee children: the case of Syrians in Turkey. International Migration, 57(2), 253-267.

Chan, J., To, H.-P. and Chan, E. (2006). Reconsidering social cohesion: developing a definition and analytical framework for empirical research. Social Indicators Research, 75(2), 273-302.

Christophersen, E. (2021, June 23). Norwegian Refugee Council (NRC). Retrieved from These 10 countries receive the most refugees: https://www.nrc.no/perspectives/2020/the-10countries-that-receive-the-most-refugees/

Chulov, M. (2014, June 16). Iraqi city of Tal Afar falls to Isis insurgents. Retrieved from The Guardian: https://www. theguardian.com/world/2014/jun/16/iraq-tal-afar-falls-isis

Corner, J. (1999). The agency of mapping: speculation, critique and intervention. In D. Cosgrove (Ed.), Mappings (p. 213254). London: Reaktion Books.

Dikeç, M. and Gilbert, L. (2002). Right to the city: homage or a new social ethics? Capitalism Nature Socialism, 13(2), 5874.

Dillioğlu, B. (2015). Suriyeli mültecilerin entegrasyonu eğitim ve istihdam politikalari. Akademik ORTA DOĞU, 10(1), $1-22$. 
Durable Solutions Platform and Migration Policy Institute. (2021). A bridge to firmer ground: learning from international experiences to support pathways to solutions in the Syrian refugee context. Durable Solutions Platform and Migration Policy Institute.

Efe, İ., Pakso, A. and Pandır, M. (2015). Türk basınında Suriyeli sığınmacı temsili üzerine bir içerik analizi. Marmara İletişim Dergisi / Marmara Journal of Communication, (24), $1-26$.

Ekinci, Y. (2015). Misafirlik dediğin üç gün olur!: Suriyeli sığınmacılar ve sosyal dişlanma. Birikim Dergisi, (311), 4854.

Eraydın, G. (2017). Migration, settlement and daily life patterns of Syrian urban refugees through time geography: a case of Önder neighborhood, Ankara. MS Thesis, Middle East Technical University, Department of City and Regional Planning, Ankara.

Erçetin, Ş. Ş. (2018). Educational development and infrastructure for immigrants and refugees. Hershey, PA: IGI Global.

Erdem, C. Y. (2017). Ottomentality: neoliberal governance of culture and neo-ottoman management of diversity. Turkish Studies, 18(4).

Erdoğan, M. M. (2015). Türkiye'deki Suriyeliler - toplumsal kabul ve uyum (1 ed.). İstanbul: İstanbul Bilgi Universitesi Yayınları.

Ergüven, N. S. (2013). Uluslararasi mülteci hukuku ve Türkiye. Ankara Üniversitesi Hukuk Fakültesi Dergisi, 62(4), 10071061.

Erman, T. (1997). Squatter (gecekondu) Housing versus Apartment Housing: Turkish Ruralto-Urban Migrant Residents' Perspectives. Habitat International, 27(1), 91106.

Festinger, L. (1950). Informal social communication. Psychol. Rev., 57, 271-282.

Forrest, R. and Kearns, A. (2001). Social Cohesion, Social Capital and the Neighbourhood. Urban Studies, 38(12), 2125-2143.

Fox TV. (2021, January 15). Retrieved from Ana Haber: https:// www.youtube.com/watch?v=4UVNdYHgcyQ

Friedkin, N. E. (2004). Social cohesion. Annual Review of Sociology, 30, 409-425.

Fuchs, C. (2019). Henri Lefebvre's theory of the production of space and the critical theory of communication. Communication Theory, 29, 129-150.

Galip, İ. (2017). Dangerous words: online citizenship and censorship in Turkey. MA Thesis, London School of Economics, Sociology.

Gebhardt, D. (2016). Re-thinking urban citizenship for immigrants from a policy perspective: the case of Barcelona. Citizenship Studies, 20(6-7), 846-866.
Gencer, T. E. (2019). Göç süreçlerindeki çocukların karşılanamayan gereksinimleri, haklara erişimleri ve beklentileri: Ankara ve Hatay'da yaşayan Suriyeli çocuklar örneği. Unpublished $\mathrm{PhD}$ Thesis, Hacettepe University, Institute of Social Sciences, Ankara.

Gökçek, A. (2017). State response to mass refugee flows: the case of Bulgarian Turks, Iraqi Kurds and Syrians in Turkey. MA Thesis, Koç University, Department of International Relations, İstanbul.

Göksu, F. (2020, April 10). Ya kentsel dönüşüm ya kat farkı . Retrieved from Sabah Gazetesi/Newspaper website: https:// www.sabah.com.tr/ankara-baskent/2020/04/10/ya-kentseldonusum-ya-kat-farki

Guest, A. M. and Wierzbicki, S. K. (1999). Social ties at the neighborhood level: two decades of GSS evidence. Urban Affairs Review, 35(1), 92-11.

Günay, B. (2012). Ankara spatial history. AESOP, 1-13.

Güngör, F. (2014). Turkoman in Iraq and the future of the Middle East in equation. International Journal of Social and Educational Sciences, 1(2), 15-43.

Gür, B. (2002). Transformation of Urban Space Through Discursive Representations in Sultanahmet, Istanbul. Space and Culture, 5(3), 237-252.

Gürboğa, N. (2016). Türk-Yunan nüfus mübadelesi ve devletin mübadil romanlara ilişkin söylem ve politikaları. YDÜ Sosyal Bilimler Dergisi, 9(1), 109-140.

Gürel, M. (2016). Seashore readings: The road from sea baths to summerhouses in mid-twentieth century izmir. In M. Gürel, Mid-Century modernism in Turkey: architecture across cultures in the 1950s and 1960s (p. 27-55). New York: Routledge.

Hewstone, M. (2015). Consequences of diversity for social cohesion and prejudice: the missing dimension of intergroup contact. Journal of Social Issues, 71(2), 417-438.

Hoffmann, S. and Samuk, S. (2016). Turkish immigration politics and the Syrian refugee crisis. Stiftung Wissenschaft und Politik / German Institute for International and Security Affairs. Berlin: Working Paper Research Division Global Issues.

Irak (Türkmen) Uyruklu Yabancılar. (2015). T.C. İçişleri Bakanlığı Göç İdaresi Genel Müdürlüğü

Yabancılar Dairesi Başkanlığı. Retrieved from: https://kms.kaysis.gov.tr/Home/Goster/140275

İçduygu, A. (2015). Syrian refugees in Turkey. The Long Road Ahead. MPI Reports.

İçduygu, A. and Şimşek, D. (2016). Syrian refugees in Turkey: towards integration policies. Turkish Policy Quarterly, 15(3), 59-69.

İçduygu, A. and Şimşek, D. (2017). Uluslararası göç, politika ve güvenlik. Toplum ve Bilim, 6-10. 
Ineli-Ciger, M. (2017). Protecting Syrians in Turkey: A Legal Analysis. International Journal of Refugee Law, 29(4), 555579

Jenson, J. (1998). Mapping social cohesion: the state of Canadian research. Canadian Policy Research Networks Inc.

Kantzara, V. (2016). Social cohesion and development. Social Cohesion and Development, 6(1), 37-50.

Karadeniz, A. (Ed.). (2020). Göç ve uyum çalıştayı - migration and cohesion Workshop. Ankara: Mamak Belediyesi Kültür ve Sosyal İşler Müdürlüğü - Mamak Municipality Directorate of Culture and Social Affairs.

Karayiğit, H. O. (2021). Maps that map the mind: Abstraction of Geography by IR Discipline. J-READING Journal of Reasearch and Didatics in Geography, 1(10), 73-92.

Kavas, A., Avşar, İ., Kadkoy, O. and Bilgiç, E. Ç. (2019). İstanbul'da Suriyeliler ve savaş sonrası Suriye gettoları. Ankara: TEPAV Yayınları.

Kaya, T. (2002). Post evaluation of physical planning experience of Ankara: 1957 Plan of Yücel-Uybadin. Unpublished Master's Thesis, Middle East Technical University, Department of City and Regional Planning, Ankara.

Keysan, A. Ö., \& Şentürk, B. (2021). Empowerment Perspectives and Practices of Refugee-Related NGOs in Turkey: Family, Protection, or Solidarity? Journal of Refugee Studies, 1(1), $1-26$

Koca, B. T. (2016). Syrian refugees in Turkey: from "guests" to "enemies"? New Perspectives on Turkey, 54, 55-75.

Kozinets, R. V. (2011). Netnography: doing ethnographic research online. Los Angeles: SAGE.

Lefebvre, H. (1991). Production of space. (D. Nicholson-Smith, Trans.) Oxford: Blackwell.

Lefebvre, H. (1996 [1968]). Writing on cities. (E. Kofman, \& E. Lebas, Trans.) Malden, MA: Blackwell Publishers.

Ljujic, V., Vedder, P., Dekker, H. and van Geel, M. (2012). Romaphobia: a unique phenomenon? Romani Studies, 22(2), 141-152.

Mahmood, H. H. (2020). Iraqi Turkmens between the past and the future: a historical critique of policies. Journal of Sociological Context, 1(1), 66-75.

Mamak Belediyesi Şehir ve Medeniyet Akademisi'nin Startı Verildi. (2020, September 7). Retrieved from Mamak Belediyesi website: https:/www.mamak.bel.tr/haber/ mamak-belediyesi-sehir-ve-medeniyet-akademisininstarti-verildi/

Marsh, A. (2010). The Gypsies in Turkey: history, ethnicity and identity - an action research strategy in practice. In D. L. Bas and T. Acton (Eds.), All Change! Romani Studies through Romani eyes (p. 27-39). University of Hertfordshire Press.
Marx, K. (1993). Production, consumption, distribution and exchange (circulation). In Grundrisse: foundations of the critique of political economy (rough draft) (p. 83-111). London: Penguin.

Mercan-Sarı, R. (2018). Irak'tan Türkiye'ye göç etmek zorunda kalan Türkmenler üzerine bir araştırma: Ankara örneği. Unpublished Master's Thesis, Hacettepe University, Department of Sociology, Ankara.

Mumcu-Uçar, O. and Özsoy, A. (2006). Sınır kavramına mekânsal bir yaklaşım: Bahçelievler örneği. itüdergisi/a, 5(2), 11-24.

Narlı, N. and Özaşçılar, M. (2020). Understanding and measuring the social inclusion of Syrian refugees in İstanbul: the case of Zeytinburnu. Refugee Survey Quarterly, 39, 299-320.

NTV. (2020, February 2). Son dakika haberi: Suriye İdlib'de 33 şehit, 32 yaralı. Retrieved from NTV News: https://www. ntv.com.tr/turkiye/son-dakika-haberi-suriye-idlibde-33sehit-32-yarali,8bKetwRLr0qSegN7DFRruA

Ongur, H. Ö. (2015). Identifying Ottomanisms: the discursive evolution of Ottoman pasts in the Turkish presents. Middle Eastern Studies, 51(3), 416-432.

Özateşler, G. (2014). Gypsy stigma and exclusion in Turkey,1970: social dynamics of exclusionary violence. New York: Palgrave Macmillan.

Özçürümez, S. and Hoxha, J. (2020). Practicing social cohesion in the dark: diverse processes and missing indicators in forced migration contexts. Frontiers in Human Dynamics, 2 .

Putnam, R. D. (2007). E Pluribus unum: diversity and community in the twenty-first century the 2006 Johan Skytte prize lecture. Scandinavian Political Studies, 30(2), 137-174

Richardson, T. and Jensen, O. B. (2003). Linking discourse and space: towards a cultural sociology of space in analysing spatial policy discourses. Urban Studies, 40(1), 7-22.

Rizzi, C. U. (2020). Antiziganism as a barrier for the Roma to access policies: the case of Romani access to education in Turkey. Ethnopolitics, 1-12.

Saggar, S., Somerville, W. and Ford, R. (2012). The impact of migration on social cohesion and integration. UK Border Agency.

Sağlik, C. (2020). Pavyon kültürünün aile hayatına etkisi. Unpublished Master's Thesis, Nevşehir University, Department of Sociology.

Şahin, M. and Duman, R. (2008). Cumhuriyetin yapılanma sürecinde müzik eğitimi. Çă̆daş Türkiye Araştırmaları Dergisi, 7(16-17), 259-272.

Saraçoğlu, C. (2008). Migration, neoliberalism and ethnicization: the middle-class construction of Kurdish migrants in Izmir, Turkey. University of Western Ontario, Sociology, London. 
Saraçoğlu, C. and Belanger, D. (2019). Loss and xenophobia in the city: contextualizing anti-Syrian sentiments in Izmir, Turkey. Patterns of Prejudice, 53(4), 363-383.

Sargin, G. A. (Ed.). (2012). Ankara Kent Atlası. Ankara: TMMOB.

Savran, S. and Sat, A. N. (2019). Exploring the locational preferences of Syrian migrants in Ankara and a case study of Önder, Ulubey, and Alemdağ neighborhoods as an ethnic urban enclave. Journal of Ankara Studies, 7(2), 283-302.

Schmid, C. (2018). Journeys through planetary urbanization: decentering perspectives on the urban. Environment and Planning D: Society and Space, 36(3), 591-610.

Schneekloth, L. H. and Shibley, R. G. (1995). Placemaking: the art and practice of building communities. New York: New York Wiley.

Seyidov, I. (2021). Understanding social cohesion from the perspective of the host community: Turkey example. Journal of Economy Culture and Society, 63, 111-125.

Sezgin, A. A. and Yolcu, T. (2016). Göç ile gelen uluslararası öğrencilerin sosyal uyum ve toplumsal kabul süreci. Humanitas, 4(7), 417-436.

Smith, N. (2008). Uneven development; nature, capital, and the production of space, ( $3 \mathrm{ed}$.). Athens and London: The University of Georgia Press.

Stratejik Plan 2015-2019. (2015). T.C. Mamak Kaymakamlığı: Mamak̇̇lçe Milli Eğitim Müdürlüğü Retrieved from: https:// mamak.meb.gov.tr/meb_iys_dosyalar/2015_11/03092732_ stratejkplan.pdf

Sunata, U. and Bircan, T. (2015). Educational assessment of Syrian refugees in Turkey. Migration Letters, 12(3), 226 237.

Taşkın, P. and Erdemli, Ö. (2018). Education for Syrian Refugees: Problems Faced by Teachers in Turkey. Eurasian Journal of Educational Research, 75, 155-178.

TDS. (2021, June 28). HAZİRAN 2021 -"AÇLIK VE YOKSULLUK SINIR" . Retrieved from Türkiye Denizciler Sendikası (TDS): http://tds.org.tr/news/haziran-2021aclik-ve-yoksulluk-sinir

Türkyılmaz, M. and Ayaokur, A. (2014). Ankara kent tarihi araştırmaları: 1923 - 2013. In A. Köroğlu (Ed.), Başkent oluşunun 90. yılında Ankara: 1923 -2013 sempozyumu, 7- 8 Ekim 2013 (p. 261 -271). Ankara: Ankara Üniversitesi.
UNDP. (2020). Strengthening social cohesion: conceptual framing and programming implications. Research Report.

UNICEF. (2021). Towards a child-led definition of social cohesion. Research Report.

Uslu, A. and Gökçe, Ş. (2010). Social interaction in urban transformation areas and the characteristics of urban outdoor spaces: a case study from Turkey. African Journal of Agricultural Research, 5(20), 2801-2810.

Üstünbici, A. (2020). 'Street-level justifications': Service providers mediating refugee reception in the urban context of Istanbul. Journal of Refugee Studies, 0(0), 1-19.

Uysal, O. (2016, June 21). Başkentray projesi. Retrieved from Rail Turkey TR: https://tr.railturkey.org/2016/06/21/ baskentray-projesi/

Uzpeder, E., Danova-Roussinova, S., Özçelik, S. and Gökçen, S. (2008). We are here! Discriminatory exclusion and struggle for rights of Roma in Turkey. Promoting Roma Rights in Turkey Project, Istanbul.

Varsanyi, M. (2006). Interrogating "Urban Citizenship" vis-avis Undocumented Migration. Citizenship Studies, 10(2), 229-249.

WFP. (2020). Social cohesion in Turkey: refugees and the host community online survey findings, round 1-5. United Nations World Food Programme Turkey Country Office. Ankara, Turkey: World Food Programme.

Woolcock, M. (2006). Social cohesion, institutions, and growth. https://www.cgdev.org/sites/default/files/9136_file_WP94. pdf

Yavuz, F. (1981). Başkent Ankara ve Jansen. METU Journal of the Faculty of Architecture, 7(1), 25-33.

Yenigün, O. and Eraydın, A. (2019). Governing urban diversity in Istanbul: Pragmatic and non-discriminatory solutions of governance initiatives in response to politicisation of diversity. European Urban and Regional Studies, 26(3), 268-282.

Yükselsin, İ. Y. (2009). Satılık havalar: Batı Türkiye Roman topluluklarında bir müziksel zanaatkarlık biçimi olarak "çalgıcılık". The Journal of International Social Research, 2(8), 452-463. 